University of Louisville

ThinkIR: The University of Louisville's Institutional Repository

Electronic Theses and Dissertations

1944

\title{
The history of the National Youth Administration in Kentucky.
}

Margaret Ruth Hopper

University of Louisville

Follow this and additional works at: https://ir.library.louisville.edu/etd

Part of the Social Work Commons

\section{Recommended Citation}

Hopper, Margaret Ruth, "The history of the National Youth Administration in Kentucky." (1944). Electronic Theses and Dissertations. Paper 1969.

https://doi.org/10.18297/etd/1969

This Master's Thesis is brought to you for free and open access by ThinkIR: The University of Louisville's Institutional Repository. It has been accepted for inclusion in Electronic Theses and Dissertations by an authorized administrator of ThinkIR: The University of Louisville's Institutional Repository. This title appears here courtesy of the author, who has retained all other copyrights. For more information, please contact thinkir@louisville.edu. 


\title{
UIIVARSITY OF IOUISVILIT
}

\author{
THI HISTORY OF THE
}

MATIONAI YOUTH ADINISTRATION III KEHTUCK

\author{
$\triangle$ Disaertation \\ Submitted to the Froulty \\ Of the Graduate Sohool of the Ouiversity of Ioulsville \\ In Partial Fulfiliment of the \\ Requiremente for the Degree \\ Of laster of Solenec in Soclal deministration
}

Craduate Division of Soolal Administration

By

WARGARET RUTH HOPFTR

Year

1944 


\section{rut 0 STUDFIT: Iargaret leth Hopper}

PITIS OF THASIS: The Hiatory of the lational

Youth Laministration in Kontuoky

LPPROTED BY READITG COLOITIRE COLPOSED OF THE FOLTOWIYG MEMBRS:

John J. Cronin

Annie Louise Pruitt

W. C. Mallalieu

HAYE OF DIRECTOR:

John J. Cronin

DATE: $2 / 12 / 44$ 


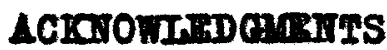

In the compliation of material used in this thesis the author Is Indebted to Mr. Ballard Morris, Manager of the Ioulatille Naster Projeot of the War Produotion Training Program of the Mational Jouth Admin18tration, Mr. Id Terry of Olerelend, Ohio, Mr. I. I. Talentine, Ira Direotor of Finance and Statiatios, Mr. Smith Rose of Iondon, Kontuoley, Ylss Margaret Kilkenny, and Mss liary Virginia Hogan. W. wish also to thank Ir. John Oronin, Director of the Graduate Division of Social Administration of the Onireraity of Iouisille and other mombers of the University faoulty for thoir counsel and enoouragement. 


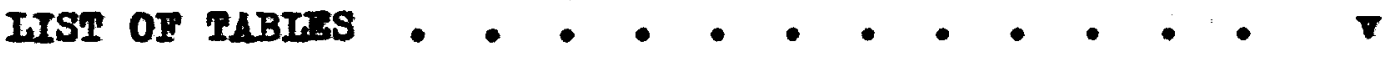

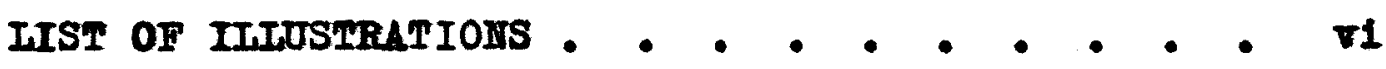
IMIRODUCTION • • • • • • • • . • . . . 1 Chapter

I. WHTUCKY III THE IATIOTAL PICTURE • • 6

The Youth Problem

The Ifew Deal Inswer

Kontuoks 1926

II. THE IIITIUI TRAR 1985-1936 - • - . 27

Organization

The In-Sehool Program

College $41 a$

Graduate 11d

High Sohool 11 d

The Ilon-Sehool Group

Togro Partlolpation

Vocational Guldance

III. THE MATURING PERIOD, JUNE, 1936 TO JUNE, 1939

Idministration

Progress of the Program

Student Ald

The Out-oI-Sohool Program

Vooational Guldanos

ipprentioe Training

Realdent Worl Conters

Expenditures

Flood Reliel lotivity

Trends 
IV. THE INATIONAL YOUTH ADMINISTRATION III DEFENSE AID TAR • • • • • • •

- Mdministratire Changes

Program Berelopments

Student Ald

Tork Projeots

Junior Placement Servioea

The number Servod

4 War Casualty

V. Conclusions • • • • • • 110

III In Kontuoky and the Youth

Problen

Implieations for the Future

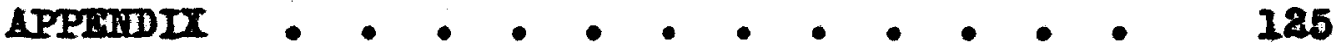

BIBLIOGR LPHY • • • • • • • • • • 129 
1. Colleges Reoelving FYA Help in Kentuoky, 1935-1936. (Showing monotary allotment, number of students alded, enrollment in 1934 and quota asaigned each.) . . . . . .

2. Undergraduate College students Lided, by Race and Sex, 1935-1936. • • • • •

3. Firat Year and Upperolass College Students dided by irr in Kentuoky, by Race, 1935-1936

4. Tumber of High Sohool Students Ingaged in Fourtoen FII Sohool lid 0oonpations in Kentuaky Dur1ng 1935-1936.

5. Types, Imount, and Values of Work Performed by wri Out-of-sohool Youth in Kontuoky Daring 1935-1986. .

6. Kentuoky Colleges Reobiving Nra Help, Number of Students and Het Payments Rooelred on Student lid Program for the Month of ootober, 1939, the Months of Haroh and Ootober 1940 Through 1942, and the Month of Maroh, 1943.

7. Kentuoky High Sohools Hooeiving NYA Help, Number of students and Net Payments Reoeived on Student A1d Program for the Wonth of Ootobor, 1239, the Yonths of Maroh and Dotober 1940 Through 1942, and the Month of Maroh, 1943.

8. Iumber of Youth Imployed and Their Rarnings on IrI Out-of-Sohool Program in Kontuoky for the Month Ootober, 1939 Through 1942 and the Konth of June, 1943. 


\section{IIST OF IILUSTRATIOIS}

Fisare

Page

1. NYa Distriots in Kontuoky Jane 1936 . .

31

2. MIL Distriots in Kantuokg Joly 1937 - . 62

3. Tra Ireas in Kontuoky Jaly 1939 - . . 92 
IXIRODUCTIOI 


\section{IHTRODUCTIOT}

One of the emorgeney coelal program sot into operation during the depreseion period by Franklin Reoserelt's Irew Deal was the Iational Jouth Maninistration. This ageney, martured in 1to beginning in 1935 under the wing of the Nork Projeets Mninistration, was eatapulted to soparate status in the Joderal socrurity useney in 1959. It orolrod lnto a War Prodnotion Training Progran in 1942. and expired gutorly when Congreas retured to grant funde for the contimed operation of the program during the Iiscal Jear, 1943-1944. The exiginal purpose of the Touth Adnlaletration wes to peorlde work rellef to nnemplojed joung people betwon the ages of 26 and 25 and to help noedy atudente romain in achool by paying wages for work perfermed under sohool anoploes. Iater the out-ofasohool phase of the offort added training couraes and initiated a resident work eonter plan for projeoting its Borvices. With the coming of the war period the entire work projeot progran was deroted to tralning young porsons for explojmont in war industries. Thet as IIA completed one gear totally gearad for war, the program was diceontinned. The purpose of this study is to reoord a chronolocleal history of the Iational Youth Aniniatration in Iontuoky. In giring a sotting for the program in this state. 
we coneldered brielly the problens faolng joung pooplo in the depreasion period and desoribod partioularly the oonattions eneountered by IYL on its arrival in rentuoky. The bedy of the disertation is deroted to recounting the manner in whioh the new agenoy mot youth diffioulties using the resourees at its oommand and dereloping new teohniques with wioh to approach the old problems. Finally we reexawine the reoord to deternine whethor or not Irs falfilled 1ts purpose in Kentuoky.

Ixperiences of the past should be of ralue in planning for the future, and it 18 our sincere hope that this acoount of the kinds of assistanoe giten by IIL, the extent of Ite operations, and the cost of the program ay sorve as a reference for individuals and groups soeking solutions to the Touth Problem in Iontuoly. At this writing in 1944 afficulties faeing young people have taken a different form from the depression trials, but it is our belier that the post-wer peried will see a vigorous recurrenes of the problems of seouring adequate eduoation, omploynent, and other jouth eseentials. Wo feel that all the information and understanding that ean be assembled on the lsgues facing Jouth will be needed if rontuolians are to be provided with widest opportunitios. IrA in this state pioneered in seroral important instances, and it is to reoord the eervices of that program that this paper 18 writton.

Iot discussed intensively here but of onsiderable 
Interest to the soolal serviee student, howerer, are the personnel reoords, opeolal studies of the jouth worker and his environment, publications of IIA, and the exporiments with resident work centers undertaken by the Youth Idminietration. Comparisons of the operation of IIA in Kentuoky and in other states would lirense be fruftrul. Because of the many phases of the work and because of the constantiy shifting nature of the program, subjects of profitable so- lal study waing IrA material are almost limitlose.

This History of the Iational Youth Ldministration In Kentuoley was began immodiately after the abolition of IIl by Congressional tote in June, 1948, and mach of the material was dxam from uppublished records, lotters, momoranda, and charts. Fortunately we were able to looate most of the Information needed for our history before the Irontroks branch of the Mational Iouth administration deatrojed all flles not requested for the natlonal records. 1 large part of the tabulated aterial on the Jouth ddministration In Kontuoky was sent to Cleveland, Ohio whon Kontuoky was made a part of Region V with Uohigan and Ohio in July, 1948, but with the assistance of $\mathrm{Ur}$. Id H. Terry, who served as Director of the Dirision of Youth Personnel in Kontuoky and later in the Personnel Dirigion of Region $T$, wo wore able to salvage the statisties whioh wore necessary to gire a ploture of the extent and the oost of the Touth Progrin in the atate. The oooperation of the personnel of 
5

IrA at a time whon a program whioh was dear to their hearts was elosing in their faces and whon thols own personal om plogment conditions wero unoertain was unstinting. Their Lindness is more than appreolated. 


\section{CHAPTER I}

KEATUCKI II THE MATIOHAL PIOTUHE 


\section{OHAPHAR I}

\section{GPPUCK IA THE IATIOKAT PICTUH}

The Touth Problem

Anong the many soolal, coonomio, and politioal problems facing the United Stater as a result of the great depression of the 1930 's was the Youth Problem. Before 1929 there had been alffioulties in the way of young poople as theg sought to build for thomselves a hom, an oronomis poation. and a atizenship that could be respected, but at no time in the history of our country had jouth come up agalnst the frustration of these alms quite so forolbiy as in the domoralizing days of the depression.

In the decades of rapid population growth and rast unsettled plaine in the western portion of this nation joung people with conrage, ambit104, and willingness to work oonla carte conomle security for themselves for little more than ataleing out a olain to their portion of our rioh nataral herltage. Host oocupations vere $1 \mathrm{mple}$ raral enterprises. and education noods were fow and rudimentary. Iot nnt12 the latter part of the nineteenth century were publ1e eduoational opportunities arallable on an extensire acale. HIgh1y epeolalized teohnologloal requiroments and solentifio 
mohanical production oame eron Iater.
The erowth of population, the effeot of industrial expansion and organization on coolety, and the oocupation of the fertile western lands have brought the lwerioan people face to face with a population problem. Various groups of the pepalation have problems peouliar to thomselres, and jouth, one of the major groups, had the related questions of education and eaploywent to solve. Job spociallzation demanded more deliberate and exacting form of rocational training; intelligent partiolpation in community effalrs called for a more extensire and prolonged period of general eduoation; and the complexity of soolal affairs required an orientation and counseling period before youth could face coeioty with any degree of understanding and self confldence.

Irolving from the olroumstances of the times was the Youth Problem with 1 ts many phases, almost as many as there were joung poople who oombined within themseltes innumerable rariations of a similar thome. In edueational opportunity arailable to indiridual young peoplo there was great inequality. Families with the largest number to edno eate had the least money to use for that purpose. Iearly a

P. O. Johnson and 0. I. Harrey, The National Youth

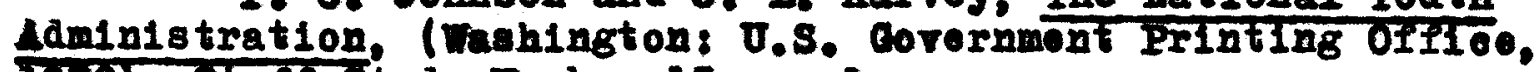
1988), Staft Study number 13, p. 1 .

2 Ibid., p. 1-8. 
oonstant inverse ratio existed betwoen the birth rate for any given group and its coonomi. status. Those families who onjoyed the richost oultural resourees railed to replace themselres, whereas those who had the lowest inoomes had the highest number of ohllaren per family. Our present secondary sohool is atill a highly seleetive institution adapted to the noeds of a anall minority of our popalation. The publis sohools of this country have beon supported on the theory that they serre as an instrument for the malntenande of equality of opportunity, but in riew of the rory groat ineqaulities in edpoational opportunity that exist, one may well question, if present tendenoles porsist, whether the public sohool gystom may not beoome a positive force in ereating those rery inequalities in Imoriean soolety whioh it was designed to raduoe.

Inother big alice of the. Youth Problem in the deprese10n period was the diffloulty of finding employment, when the sohool experience had ended. The gap existing between achool and omplojwent reachod ominous proportions. In Yaryland in 2985 it was found that between $40 \%$ and $46 \%$ of out-of-sohool and omplojable jouth did not obtain fulltime omploymont at the expiration of a jear after leaving sehool. The arerage period of delay at that time for the Howara 4. Bell, Jouth Tell Their Story, (Tashington: imerican Counoll on idueation, 1938), "joreword." 
Jouth who dropped out of sohool before the age of 16 was three and a half years, and the arerage duration of unemplojment of all jouth was a yoar and eleven months. Imontyalx por cent had nover been employed. It was estimated that the number of young people out of work in 1936 for the country as a wholo was 4,700,000. Phis moant that orer a third of all unemplojed were betwoen 16 and 24 jears of age. From ene-11fth to oxe-fourth of those who had jobs worked only part timo. The number of joblese raried with the eoonomio conditions, and during the most serere depression jears at least two joung persons out of $11 \mathrm{ve}$, the country over, who sought jobs were unable to elnd them.

Related to the two najor noeds, adequato edueation and explojmont opportunity, whioh faoed depression youth were the other phases of the Youth Problem. Lnong these was the foeling of eoonomio seourity whioh was largely absent in adults as well as jouth in those dags. Mile unemployment was widespread, omplojed youth faoed serious difflwat1es. Rates of pay were 10w; hours wore long; mang youth had to contribute to the support of their families. So many jobs led only to blind alleje. A large number of persons prefored professional or semi-professional oocupations, but the majority were foreed into unskilled and semi-akilied

\footnotetext{
roid.

Iaxwell s. Stewart, Youth in the Morld of Today, 3 (Iew Tork: Publio iffairs Comitto,, Incorporated, 1938),P.3.
} 
11

worl. Touth seomed to be oonfronted with an oocupational Iuture In an industrial eoonomy that was boooming more moohanized, loss conoerned with highly dereloped mochanieal ok121\%, less given to praotical instruotion outalde the inanstrial plant, and more insecure for the laborer wth a aingle reoational okill. Adequate guldance would have helped alleriate some of the employment diffioultios, but only a small minority of youth were reoelving angthing like sueflolent rooational guidance. The inereasing complexity of twontioth oentury 11 ving oombined with the depressionle alsappointmonts made the future seon dismal and the present hopelessiy confueed.

rocational training was insuffieient. There was too 21ttle relationship between the types of jobs youth entered and the training whioh they had reeeired. Oecupational training faoliftios for trade omplojmont in mural areas was practieally nonexistent. Jot only were roeational schools 1nadequate, but secondary sohools as woll offered an 111sulted program to a large peroentage of youth attending them. It acemed l1kely that soon almost 200 per oont of jouth would remain in sohool up to the age of 18 or throvgh soulor high sohool. Obrlously the high sohool oirrioulum whioh had been arewn up as oollege preparatory would no longer met the needs of all the poople, a oomparatirely

Ioll, op. olt., Mroresord."
$2_{\text {rold. }}^{\text {Bor }}$


anall proportion of whioh could expect to enter college. Some unemplojed jouth would like to return to sohool to contime atudies economle necoesity had foreed them to terminate. Often, however, the echool program had nothing more to offer that interested then, or the costs of further sohooling wore prohibitive. Even when oducation itself was Iroe, mainterance costs prevented many jouth from arailing themselres of exteting faelilties. Soelal workers and sohool prinolpalo attest to the faot that ohlldren of lower lnoome brackets arop ont of achool earliest, and gonerally the representation of students in college is direatly related to family inoome. Iren before the depreselon college opportunity wes sometimes provided needy youth by soholarships, 10r tultion fees, and alternate periods of work and study, but it was not until the depression that it was generally reoognized that there is a almilar need for finanoial assistanoo to high school stu1 dente.

In times of mass unemployment, short working hours, and 20w pay the use of 1018uro timo emerges as a soolal problon. In o1t108 the quastion of rooreation is largely ore of money. Ifth income dom oommerolal ontertainmont could be purchased 1088 often. Yany of the almple outdoor amperments are no longer possible oither in the eountry or the o1ty. Small homes do not lend thomselres to attraotive

\footnotetext{
Johnson and Harrey, Op. O1t. p. 5.
} 
sooial gatheringe. There 18 often littlo oholoo but to $200 \mathrm{x}$ outeide the home for tun. Iren for those with jobs there is unually a lot of leisure time. With little money the Iinding of satiafactory reoreation represents a rery real problom, -omparable to that of finding a job.

unothor noed of jouth is health eduoation, inoluding coelal and personal hygiene. In addition the question of jouth attitudes toward secial iseues and the implieations of these attitudes for oftizenship derelopment are major national conoerns. Touth's indifference to the ballot and 8 general seorn for pelition, although regretable, is ofton a reflexion of adult opinion. Ionetholess further eduoation to ofrlo responsibilities and the ralue of indiridual op1nion and inftiative mast bo offered if jouth is to booome rersed in the oftisenship on which progressive demooracy 18 Iounded.

There is noed for community planning for youth. The organization of sooial servioe work in the Dnited States 1s rory complex. Composed of a network of ageno1es, 100al, county, state, and foderal; publ10, pritate, and somi-prirate; rel1g10us, philanthropio, and profit-maring, the so-lal organization has been motivated largely by indiridual1sm and laisecs-faire. With 11ttlo consolous coolal plan-

Istewart, op. o1t., p. 25.
$z_{\text {Boll, op. olt., "Foreword." }}$


ning ingtitutions and agenoles arose whonerer needs were reoognized. Our hundreds of agenoies offer no well integrated program for the handing of community problems. There are wide gaps in our servioes to youth, partioularly for those in the older age groups. Orten agenoles worl with littie or no regard for one another with the result that the treatment of soolal probleme is undertaken by inatitutions or agenoles aoting in tholr indiridual capaelties rather than from a unified approaoh.

Ind 80, the Youth Problem rereals Itaelf a manyalded issue requiring an equalls oomplex solution. Unomploged youth out of school were ourght in an alley with two blind ends. On the one hand, without training or experionce they were of littlo if ang ralue to an employer; ourrent laws relating to acoldent llability and ingurance inIluenoed employers to give preforenoe to older jouth; and the domand for highor encational qualifications has grom wore and more insistent. On the other hand, without resonrces to prolong their sohooling, or without oonfidence in the programs offered by the sohoole, these unemployed jouth could not afford further vocational proparation conduclre to a liring mage. Is a result, unless giten direot eneouragement and oonsiderable rehabliltation; thos almost ineritably constituted a foeu of soclal maladjustment.

\footnotetext{
$\overline{I_{\text {Ib }} .}$
} 
Opon thom was the ourse of not being wanted with all its conoomitants of Insecurity and personality disintegration. The possibilitieg of their engaging in ant1-80e1al beharior under such olreumstances were obvious. Thus faolng the nation during the depression jears, along with many other symptoms of a diseased coonomy, was the Youth Problem beconing inoreasingly serlous as the lean jears took their toll of youthelul optimise and the will to do. Farly in the administration of Franklin Rooserelt this condition was reeognised, and plans were latd to assist joung poople to IInd a way out of the alley of two blind onds.

\section{THE IIET DEL AISUAR}

The Youth Problem eridently had forced 1 tself sufflelentis upon the coneclouenese of the nation for the Congrese to be able at the outaet of the Rooserelt Mdministration to oreate an agenoy for the benefit of unemploged Jouth. The new federal ageney, the Civilian Conservation Corps, sot up in Apr11 1983 put 250,000 unmarriod young men betwoen the ages of 18 and 25. Irom families on publio re11ef rolls, to work in forestry, park, and so1l-arosion campa throughout the country. Almost immediately thio progran won general public approval. To the triple o constitrenoy wore added gome 28,000 war reterans, 14,800 Indians, 
and searly 85,000 older wen from rellef rolls in areas noar OCC eamps. BY 1935 the age linita wore spread to Inelude young wan Irom 27 to 28 . Angust, 1935 ean the peal of the 000 program with 505,782 enrolleos.

At the outset the 000 was thought of primarily as a consertation and rellef progran designed to acoomodate only a emall eegment of needy jouth. Lt first little attention was given general edueation or occupational training of the boge although 84 per oont of thom had not comploted high echool. It per oent had not completed the elementary grades, and sow were 1lilterate. In later jears the edneational program of CCC was eonelderably expanded, but the cost of 00C, approximatoly \$1200 annually for each onrollec, limited the number of partiolpants, and, moreorer, the program offered nothing to girle.

Inter in 1933, after considering several sohomes, the Unitersity of Minnesota began a program of student aid at the oollege lerel, supported by runds provided from the Federal hangenoy Rellet Administration. In February of the next joar this form of ald, atill under the control of the FBR wa extended throughout the country, and involved prier to the eatablishmont of the Torks Progress Administration, a

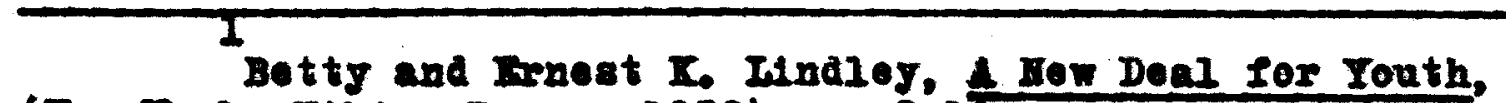
(Iow York: Viking Press, 1938), p. 9-10. 2 Ibia., D. 10 . 
total expenditure of almoat $\$ 15,000,000 .^{1}$ som 75,000 students carned an arerage of $\$ 15$ a month on work projeots dereloped by the colleges.

During 1934 Firh sat up aeroral edueational oampe Ior unemployed young women. This project grem to encompass 47 camps with an enrollment of 3000 womon, most of whom were 20 to 25 years of age. For perlods of one to four months they were giten elementary training in home coonomios, care of health, $81 \mathrm{mple}$ tjpes of handoratt such as book-repairlag, the preparation of horpital and household supplies, and varlous ereative arts.

Wth the beginning of eoonomite recotery the shortage of skllled workers in many lines was revealed. In June, 1934 the Prealdent oreated a Federal comittee on Apprentice Training to help the states to Inaugurate or continue programs in accordance with basio standarde for apprentice training." 4

Daring the pit-depression period of 1932 and early 1983 thousands of joung people mummed" their way around the country. Transient camps get up by FrR gare temporary care to youth on the road; in Lay 1935 54,000 jouth were in transiont oamps. Some older youth found emergeney omploy-

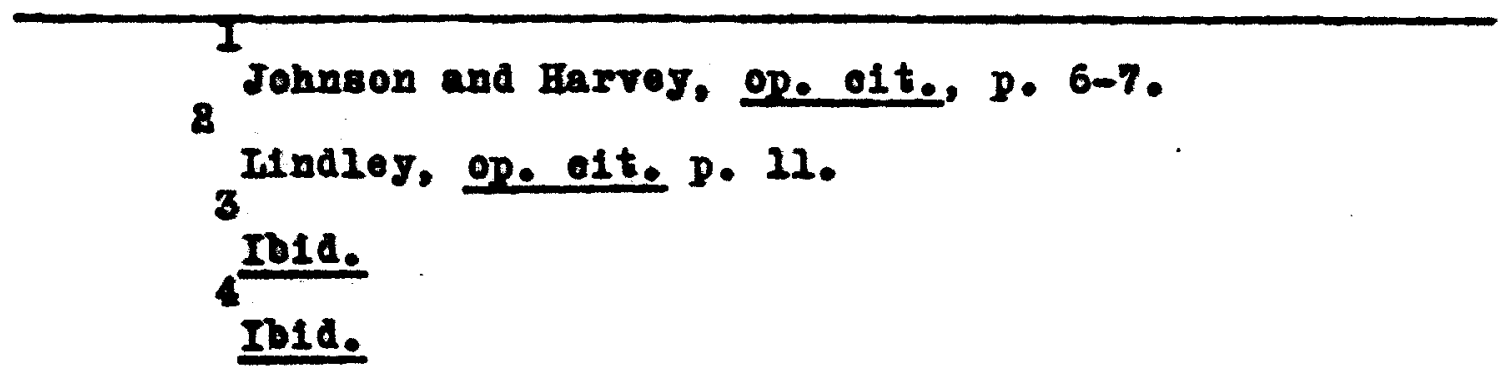


mont with FriR, the Oivil Works ridministration, and the Torks Progreas Ldministration. Another service to youth was the nse of Feth, OWh, WPA, and PWL Iunds to ronotate cohool buildings and ether educational faollities through1 out the country. The first two gears of the IIOW Deal, then, wituesed sereral major experiments as the federal governnont took orer more and more the burden of relief whioh threatened to benkrugt both muleipalities and states. In 1935 these were nearly $21,000,000$ Jouth between the ages 16 and 24 jeare in the Onited States, of wom approximately 5,000,000 were out of sohool and unemplojed. Iot inoluding CCC oams or other apoolal foderal programs there were $2,877,000$ gouth on relief wore than $1,250,000$ of whom were seeking work but could not find it. 4 majority had no skills. Wost of all they noeded regular aotivity and the feeling of being useful. The magnitude and the $10 n g$ term soolal hasards of the 1 die jouth problom beeame more apparent in 1938 and 1934, and oocnizant indiriduals began to urge the foderal gorernment to try to treat the condition wre comprohonstrely. Anong the most influential were urs. Franilin Rooserelt, Ir. Charles W. Tause18, President of the Amertean Molacese Company, Mr. Harry I. Hopkins, Ftrh ldmin-

\footnotetext{
1

Io1d. p. 11-12.

Anbrey Filliams, Report of the Iational Youth 1 dministration, (Washington; mimographed, Yay 16, 1939), p. 1.
} 
Istrator, and other offielals of Find, the Children's Burean, and the Office of Fdueation. President Roosotelt folt at elret that the 000 program, oolloge ald, and the other omergenes program whioh affected youth were all of the relief appropriations that could be rightfully labelled for youth. Ho felt concern, too, that a federal jouth ageney wight be construed as a etop toward the political orgenizetion and rogimentation of youth. In the spring of 1935 following the appropriation of $\$ 4,880,000,000$ for work rellef, he deelded to take the risk. On June 26, 1985, he estabIlshed by Iroeutite Order Io. 7086 the Irational Iouth LAniniatration and tentatively allotted for 1 ts neo during the cuaring Ileos joar $150,000,000$.

The two major objectives of the progran wore:

2. To provide Iunds for the part-timo ouployment of needy sohool, 00110ge, and graduate atudonts 16 to 24 geara of ago so as to enable then to continke tholr edroetion; and

2. To provide funds for the part-timo omplorment of gouth from rollef families on work projeets dealgned not only to efre the joung people raluable worl experienoe, but also to benelit the sommanties in whiob they $11 \mathrm{re}$.

Four gorernment ageneles wiched to admintster the program. Competition wo espocially spirited between the

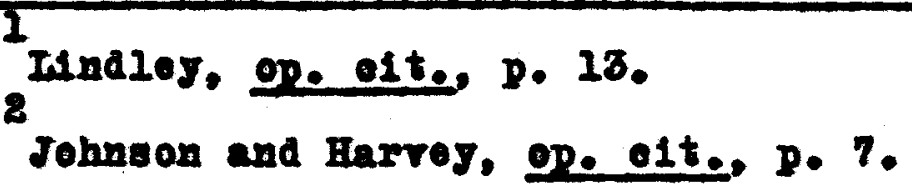


Office of Edueation and the rollef offleials. The President finally dosignated 20. Lubrey Williams, Deputy IPL Ldninistrator as Ixocritive Director of IIL. Two committecs gave other groups a rolee in the drafting of the program. in executire committec of dopartmontal offleials and a lational Advisory Comittee made up of 35 representatives of basiness, 10bor, agriculture, eduention, oburoh and welfare groups, and jouth were appointed.

III took orer Irom Frid the 0011080 atudent ald plan and expanded it in two direotions to inolude a fow graduato strdents and a large number of high sohool boys and girle. Three other main divisions of work were set up inoluding part-timo work for out-of-nohool and out-ol-work gouth in rellef familles, related tralning and oneouragement of constractive leivure time setirity for those routh, and rocatlonal guldance and placement for all unomploged gouth. Uno inhorited Irom Fikh were the edusational eampe for unemployed joung women whioh were condueted for two yoare and elosed when IrA offielals arrited at the conolustion that all that wes done in these camps could be dose more efflelently by other mothods. Tomporarily IIA tool orer the Ilnanolng and superrision of the Federal Committee on Apprentice Training, but on June 1, 1937 this comittee wes

$$
\text { Indieg, ope eit., p. } 14 .
$$


21

transferred to the Dopartmont of Iabor.

In addition to an axecratite direetor and the exeontive and national comelttees, a deputy exeoutive alreetor and Jouth adminiatrators in erery State, the Distriot of Columbia and in Iow Fork Oity wore appointed. State advisory comnittees were named by the national excoutite direotor to adviee as to the most desirable tjpe of jouth program for the State, to offer proposale for the derelopment and expontion of the program, and to promoto interest in 1 . Each state direetor sot up naobinery for the administration of the Iational Youth Ldministration program in his state dirtaing his ares into distriots, each usually comprising soreral oounties. For each distriot a supervisor was appolnted, and responsible to distriot oupervisors were projeot experrisors who provided direot oontact between the Youth Ldministration and the young poople engaged in 1 ts projeots. Iooal adrisery committees organized rariously on a distriot, county, or other community basis agaigted loeal - fleiale by aponsoring projeots, obtaining contributions, planning projeots, interpreting jouth needs, and promoting the program generally. IrA worled in elose oopperation with 100al, stato, and other foderal corernmental agenoles and with numerous nongoternmental organizations lnolnding the

Ibla.e p. 14-15.
Johneon and Barvey, op. o1t., p. 9-11.


oelleges and high sohools that administered student ild.

Dae to the Ilmited amount of money appropriated, whioh amounted to about $\$ 10$ per 1 d 10 youth and the torms of the appropriation it wes neoeseary to give first attention to jouth in families on rellef. In the beglaning three baato deelatous were reached; that the administration of tho program should be decentrallzed, that the Inllest efforts should be ande to enlist the aetive cooperation of ald stato and loeal ageneles interested in jouth, and that ample roon ahould be lort lor experiment.

Leoerdingly the youth program was launched in the ganmer of 1985 and got under full Bwing during the fall gohool semester of that joar. Prooeoding as planned the program was adepted to the states and the stuations prom gented by their $100 a$ commanties.

\section{KA:FUOK 1935}

To nuderstand the story of the Iational Youth Laministration in Fentuok it will bo helpfal to keop in mind the geographie and economio Iactors which alfoot the standard of living and the oulture patterns of the inhabitante of the state. Kentuely we explored and opened for settlement 
by the eolorful trapper and hunter, Daniel Boone, and beosme the seoond state admitted to the unlon. Ilthough a bordor state Kentroky is located just south of the Ohio R1rer IIne, and It has the aspoets of the southern group. It was eatimated in 1935 there were 2,614,589 inhabitants, and the state comprises an ares of 40,598 square miles. Only two states, Texas and Coorgia, have a larger number of counties, and Kontueklans take boundaries seriously even to the extent of putting county names on automobile lieonse 1 plates.

From a goographio and coonomis standpolnt, and in the minds of her eitizens, Kentuoley is airided into fire soetione, each with oertain charaoteristios. In the extreme western acotion of the State 18 the Jackson Parchase bounded by the Oh10, MAssissippl, and Tennessed Riters and the Tonnessev 11ne. This is largely a farming area with cotton, tobacoo, and corn bolng raiaed. The largost ofty in the Purohase 18 Paducah, population 33,641, famous as the homo of Irvin S. Oobb. Last of the Parchase 18 the Ponnyrilo rogion, also a farming sootion with mostis dark tobacco and corn belng raised. Here aro carernous limestone paseages, notabiy rammoth Care. Droopt for a fov counties in whioh

General Report, Resume of Kentuoky Youth Program, April 25, 1936, iational Youth Ldminlstration for Kontuoky, atate offloo files. 
ood mining is done, the Ponngrile is typloaliy rural with a mixtare of good and poor land. There are no largo olties in this region.

Hext moving east 18 the Kabs, the least definite of the reglons eonsisting of rolling, unfortile lands in the ahape of a horseghoe, whioh separates the Bluegrass region Iron the Ponnyrile and from the Iountains. The Iamous Bluegrase reglon of Kentuoky is the center of the burloy tobaeco and thorough-bred horse industries and contalus som of the largest farms and sone of the riohost farm land In the country. Inay of 1 ts counties have considerablo walth, but some of the finest farms are omed by persons not 1171 ing in the state. Ihis too 18 a rural section its largest olty being Iexington with a population about 50,000 . In the Eastern and Southeastorn acotions of the atate are the Kentreky uountaing, home of the purest inglo-sexon etoek in Aneriea, but beset with the perplexing problems of alminIohing natural resonrees and little available farn land. Here there are some agxionlture and extensive mining. Leh1and, population $30,000,18$ located 1 in the northern section of the nountalne and Is tho principal industrial oonter of that reg10n. Harlan County, Boone of manj mountain shoot1ngs, Is a coal mining conter sald to bo the most densely 
populated rural area in the Oulted States.

Iouiarilize. Fontuoky's only large eity, population 319,077 in 1940, (1943 ostimates place motropolitan Loulsville in the half million olasa) is located on the Ohio River. Desplte the elfy's ales, domtom Iouiarille gives the Impression of a moh enalior commanity as there are fow tall bulldings, and one thoroughfare, Fourth Street, 18 trely the main streot" of Ioulerille. Wroept for the oftios already mentloned the only centers of large population are Corlagton and Iorport in northern rantnoky, whioh are direotly aeross the rivor from Oinoinnati and comprise a part of 1ts trade area. With these areas as exoeptions, Kentrokg's problems are almost entirely raral. Fransportation in may acotions 18 poor, and some roads aro imassablo at certain seasone. Le a contrast to wealthy Jefforson and Fayette counties, Yonifee County in 1985 had no rallroad, drag atore, or bank, and had just reoontly aoquired a dootor; Illott County had only 2 telephones and 11 radios; Jartin and Ioslie Counties had almost nothing, and until chortly before 1935 not eren a road.

\footnotetext{
Io1de Popelation of the Onited States, Censue of 1940, p.

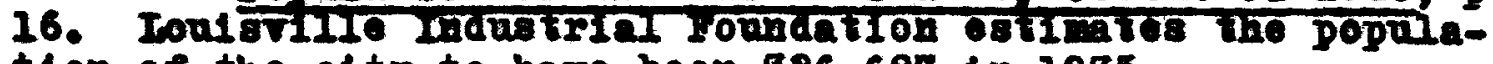
t10n of the ofty to have been 826,687 in 1935 . 3 Ceneral Report, ope olt.
} 
The 1930 Dnited States Census showed 428,845 jouth in rentuoky. This number can be broken down into the following elassifloation.

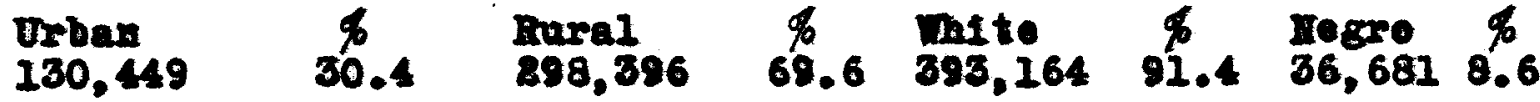
By age groupe and sex elaseifieation rereals the following: 16-17 Jears of age, $105,682(24.6 \%)$ vale $818,511(49.6 \%)$ 18-24 jears of age, 328, 283 (75.4\%) Jomale 215,334 (50.2\%)

There were 94,400 reller jouth in Kentuoky in Yay, 1936. Of this group there wore:

Urban Iural

$$
18,800(12.9 \%)
$$$$
88,800(87.1 \%)
$$

mite $88,900(94.2 \%)$

Itosro and other 5,500 (5.8\%)

16-17 joars of age, 24,700 (26.8\%) 15ale 45,000, (47.7\%) 18-24 Jears of age, 69,700 (73.8\%) Fomale 49,400,(52.3\%)

It should be kept in mind wile interproting these Ilgures that the pereontage of gouth in rural areas is molh larger than in the urban seotions in Kontuoky, and the per oent of these between 16-17 18 larger than any two year division of the 18-24 age group.

Youth in Kentuoky during the depression years faced woh the same problems as other young people in the bation exeept that a largor portion of the diffioultios were rural in nature. The Hatlonal Youth Administration brought with it hope for partial solution at least of some of the hardships.

Ot18 c. Anis, Basio Information on IIA Noriers in Kentuck, (Prepared on ild lork Projoct undor expertision of the DIfision of Iduoational Ald, November 1, 1936), p. B-6. 
OHIPIH: II

ThI IRTIU YRAR 


\section{CHIPIMR II}

\section{THI IIITIN YR}

\section{Organiration}

The lirgt meeting of the Iational darieory committo of the Iational Touth Liministration wa held urguet 15. 1935, and chortiy aftermard ith the conflrwation of thelr eppolatmont in Iarhington, the state Direotore were aesenbled for conforene with the nationel administrative and adrisory offlolale. The purpose, soope, a1ms, and organisation of administrative forees for the new Youth Program were alsonased and plane Ior a nation wide set-up woro dram Ieaving the organization of the adninistrative personnel in each state largely to the State Direotore.

By the midale of September Tr. Frank D. Paterson, Kontueky IXI Difeotor, had appointed and had had approved by Wahington a olerieal staff and administratire aselatants 1neluding nobert $K$. Salyers, Aseletant Direotor lon a part time basis from the Duirereity of Eentueky), Otis 0 . Anis. Disecter of Tocational Information and Commanity lotivities, and Lroh Bennett, Direotor, Worke Projoote Information.

\section{Indiey, op. olt.e g.x and $z$ and I.I. Valentine,}

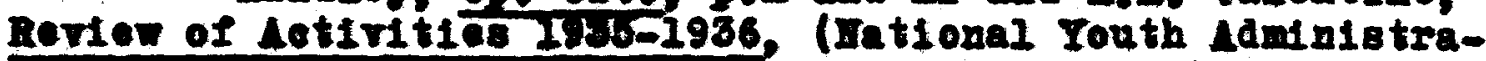

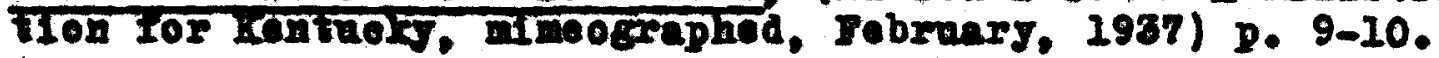


Directore of reglonal offiees to be establishod in Lshland, Corington, and Padueah had been tentatirely seleoted. I state Ldrisory Comitteo had boon named, and the llot gent to Washington, but $\mathrm{Mr}$. W1111ams reguested that a mixed board De set up. At Iirst ir. Poterson ald not oonsider it advisable to ask a Iogro to aerve on the state Advisory Comnittoe in Nour border line state." Subecuentig both youth and Fogrose were giten representation, howerer. I County Fouth Oounolis were also appointed tentatively, and in the first month of operation the state offled oontaoted the following organizations interested in joung poople: Parent-Fecchor Lsoolations, Momon's Olubs, Boy and Girl Seonts, Young Yon's and Young Tomen's Chriatian Lssoolations, Imorioan IeElon, Sorrice 01ubs, county and home demonstration agents, Iraternal organizations, ohuroh groups, park and plajeround offlelals, chambers of commorce, elty and county offlolals, labor sroups, and welfare agenoles, namely Red Crose, Salration Lrwy, ohild wolfare bureans, and family sooleties." The Kontueky State Adrisorg Combittee held its first moeting Ootober 25 in Iouiarille. Yombers of this group cam trom different seotions of the state and brought with them experienos in induetry, agrieulture, edueation, and

\footnotetext{
See uppendix \& for a list of the firet Kontuchy Adrisory Cound teo mombore. 8 Irank D. Peterson, "First Report to mahington," Soptomber, 1935, p. 1,8.
} 
commoree. The Gomnttee discussed the national polieies of IYh, and the mombers were asked to give publielty and assiat In stimalating intereat in the now progran as woll as to advise the state administration in the formalation of plans ouitable to the operation of IrA in rontuoky. By Iotember 1. County Youth Couno1ls oomposed of from fire to nine mombere were eet up in each of the 180 counties in the state. Those ooune1ls included aroh community leaders as county offielals, cducators, connty agrioulture agente, representatires of many organization interested in young poople, and the county relief woricer. Among the functions suggested to these groups we the talding of a survey of youth neads and maing a study of looal fac1lities set up to moet these needs.

Lt the same time that the adrisory groups were being formal a divieion of administrative authority throughout the ctate was taking plaoe. Six diatriots woro lald out each 1roluding a number of counties. A distriot manager was pleoed orer each and made member of the state adminlstrative staff. These managers reperted direotiy to the state offles and recelred instructions Irom the atate depertmental heads. Nost of the efforts of these managers to derelop the 


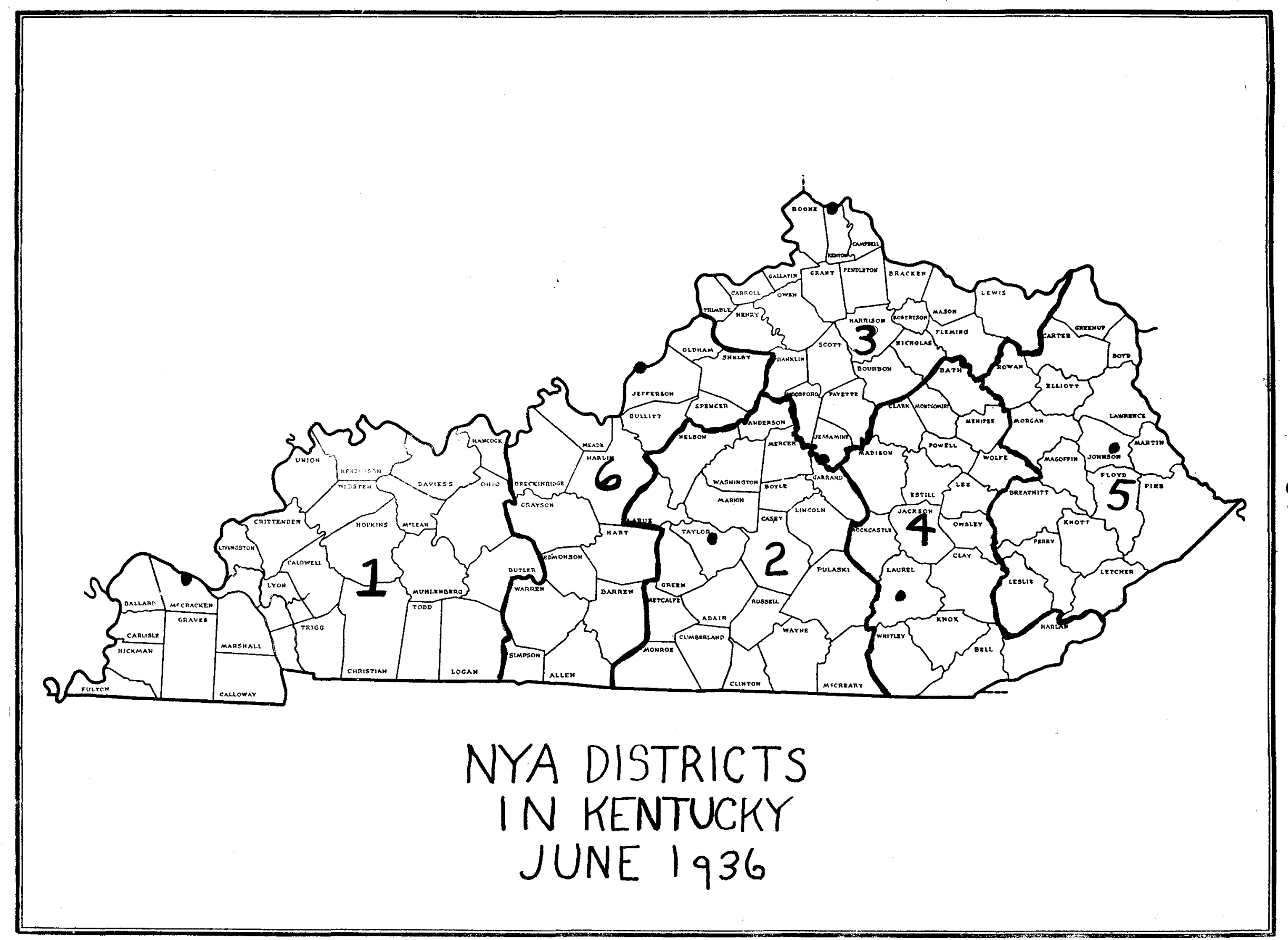

$F_{i_{B}} . I$ 
progran of IrA within their territory were in oonjunotion with loos county Youth Coune118. Ulhough it would here been pessible to work alreetly with the jouth thomselves, it wa felt to be wise soolal polloy and helpful in gaining support for the program to interpret and gain interpretat10ns Iron the eltisenry of the commanition which IrA hoped 1 to serve.

Ith the appointment of anfiofent personnel and the aharing of monledge as to 1 ts purpose the Fontuoky Youth Program was ready to holp .. . - do conething for tho nation's nemployed youth" who ought to have their chance in sohool, their turn as apprentioes, and their opportunity for Jobs.

\section{THE II-SCHOOL PROGLAX}

lfter considering how best to adminiater the Youth Program in order to moet the noods of all ollefble youth, if posalble, It was agreed by the nationel administrators that the program be divided into two major categories. One group was termed the sohool group and the other ealled the nonsehool group. Firet wo shall examine the proeess by which

\footnotetext{
Teterson, Monthly Report to Wahington," Deeember, 1955, P. 8 .
}

Franklin Roosorelt, statenent on elgning Ixeoutive Oxder He. 7086, June 26, 1985. 
the program for the cohool group wa eot into operetion in Tantueky.

\section{Collere 4d.--For effidenoy in administration tho} gohool group was alvided into three claseifleations based on grade lerel. There were graduate ald, 001lege aid, and assistance for high sohool studente know as sohool lid. In order to get the Youth Laminietration in operation in timo for the beglnuing of the academie year, 1985-1936, the Kentuoky state IrA office Invited ropresontatives of Kentuoky 00110ges to moet in Iovistille, ungust 27. All Kontuoky eolleges exuept two small junior oolleges were represented at th1s conference. In explanation of the program was giren, applioation blanks were passed out, and projeots for the student ald partieipants wore disoussed.

To be eligible for employment from the undergraduate college Lid program according to standards set up by the Iational IrY offioe a student had to be able to do "high grade" oollege worl, had to be finanoially unable to attond oollege without assistance, and should earry at least threefourthe of the normal olage program required by the oollege attended. Strdents were not required to be residents of the atate in whioh the oollege attended was 100atod. All Institutions of college grade, publie and prirate were eligible to partiolpate in the program provided they wore non-profit

\footnotetext{
Peterson, First Roport to Dashington". September, 1955, p. 1 .
} 
making in eharaoter. The Kontucky State Depertmont of Education had final anthority in dotormining eligibility.

Cuotas wore assigned ench college on the basts of the eollege enrollment of Oetober, 1934, the gear bofore IIL was eatabliahod. 4 muber of atudents equal to twolve per cont of the college enroliment at that time was ontitied to roceive amplojment at an average rate of $\$ 15.00$ a month. The money allotmont giton eseh college was based on this quota. The number to receire IIf in eaoh college was not inflexible, and in the first year because the $00110 \mathrm{ges}$ were not able to get under way at the beginning of the sohool term the to laok of organization, beasuse many colleges deeided to "apread" the runds by lowering the amount paid each atudent, and because a supplementary amount ws giten IYL in Kontualy, the colleges ald not remaln within their quota Iimite but cranted help to more otudente than their quotas oalled for. The plan of "epreading" allotmants orer more students with approval by the state and national IIS 0.110es.

It becane the polloy of the student ald program in Kontuoky to determine elfolbility and administor funds in as decontralised a nanor as posstble. Uanally one of the colloge adminlatratore or faoulty mombers sorrod without oompensation as Irl administrator. He determined oligibility,

Iralentine, op. olt, p. 13.
${ }_{\text {Iold., p. 16. }}$


eselgwed fobs, kopt time, and assumed responsibllity for the program in h1s oollege. In making applioation for part-timo omplojment through Ir/, studente wore adrised to apply through either the college prealdent or the Ira supervisor In the oollege. The Fational Youth Ldminiatration aooepted the rocommondation of school offielals as long as tho college romalned within the Iinanolal limitations agroed upon. If the institution in wioh the prospective student wishod to enroll had no openings, It was aregested that ho investigate other colleges that interested hin to learn if thoir quotas had boen I11led.

The determining of which student applieants could do "good work" left to the oolleges to deeide. The state office did not set up a soholastio standard to whioh all elifible students should measure up. Varlous sohools used different mothods for determining the aeademio roquiremont. Unually an arerage grade of no" or higher was ox8

peotod. Iormer sohool records were nsed at first applieat10n, and the malntenanoe of good atanding was expeoted. Some institutions asked that three oortifleations of finanolal need on the part of students aocompany applieations. These certifloatione could be sigmed by professional or

\footnotetext{
$I$

Iblde

Peterson, Frank D., Radio Disoussion of Youth Pro-

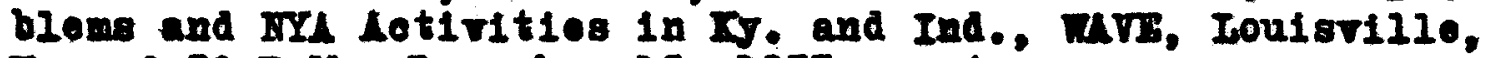
Ky., 6:30 P.X., December 15, 1937, P. 4.
} 
prominent business men in the community.

Deefision as to the type of employment mas left

largely to the colloge preaidents and IrA supervisor with the state IIL offloe offering numorous suggestions whioh serted as basi for the planning of the colleges. For misuse of IIL funds a college could have been dropped from the liat of elfible institutions and the allotment might have been distributed among the other lastitutions in the state. It wa particularly omphasized that IIA fonds were not to be used as mothod of reduelng the sohool expenses by bolng substituted fer payaent to other atudents who wore anloged and pald by the oollege. The Youth Administration me eleerely intended to supplement regalar eollege omploynent.

Inong the suggested aetivities for whioh students might receive Iational Jouth Ldministration ald were the following:

(1) Indiridenal instruation and tutoring in academi oubjects to other studonts noeding suoh holp but nnable to pay for it themalrex.

(2) Reereational instruotion in nearby ining or industrial oommunities in woh aotiritios as beskotball, rolley ball, baseball, or swiming.

(3) Sootal Vilfare Vork. College students could be eselgned to assist looal welfare ageneies in the colIeotion of data, compling statis-

Valentine, or. olt. p. 14-15. 
tion as well as the routine function of the ageney.

(1) Forrame. Disoussion Eroups on sootal Ieaves wro encouraced.

(5) IYA workere might be enlisted in blologloal, hiat orioal, ohemioal. perchologteal and other types of roBoaroh.

(6) Proparing bibliographioal material Ior campus or oommunity ageneles, re-catalogueing, and other 11 brary Tunetions protide jobs for atudents.

(7) Clerioal work other than the routine provodure could be done by IrA studeats. The asaembling of new mater1als on student brdgets and expenaitures, enorgeney tjping, liling, tabrating, to. offored employment.

(8) Tork in Iine arte by qualified atudents was an appropriate IrI Iunet10z. The lettering and designing of posters and other publiolty in connection with health, safety, and other publis welfare campalgms was rusgested.

(9) There were mamerous commanity agenQ10s such as the Boy and Girl Scouts, dey uxreeries, comounity health serTiees and othore wioh might bo gerved.

\section{2}

A record of the time apent in each of these or other oocupations by III atudenta wa kept by the oollege offI01als. Jpon reoelving this roport the atate Ir offled paid by oheer the student seelpiente through the colloge aupervi80r. During the firgt year of ite operation in Kontuoky 2,896 undergraduate college atudenta were firen emplojment by the use of $\$ 231,861.50$ Irom the IrA. Below is ahown a

Inide, p. 14.


TIBTE 2

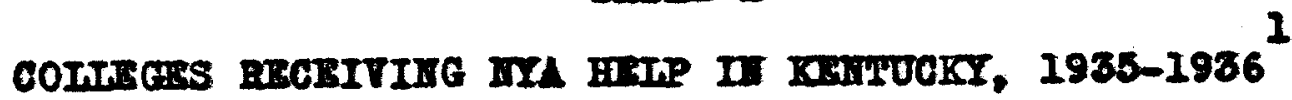

\begin{tabular}{|c|c|c|c|c|}
\hline conses & ArTothat & $\begin{array}{l}\text { Syuvenints } \\
\text { AIDED }\end{array}$ & 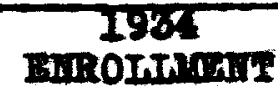 & Ton ins \\
\hline 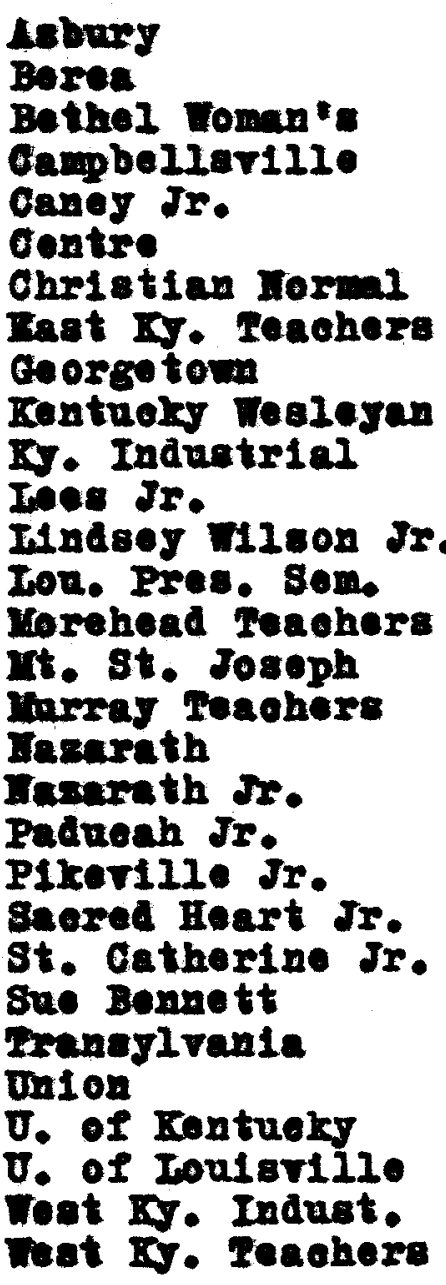 & $\begin{array}{r}7,915.00 \\
1,910.00 \\
1,990.00 \\
2,887.50 \\
1,585.00 \\
6,120.00 \\
910.00 \\
14,805.00 \\
5,665.00 \\
3,865.00 \\
8,145.00 \\
3,838.00 \\
2,260.00 \\
1,410.00 \\
10,695.00 \\
1,460.00 \\
13,785.00 \\
2,395.00 \\
1,885.00 \\
1,34.050 \\
5,040.00 \\
1,990.00 \\
1,807.00 \\
3,165.00 \\
8,070.00 \\
4,410.00 \\
48,105.00 \\
72,592.00 \\
3,880.00 \\
84,480.50\end{array}$ & $\begin{array}{r}76 \\
102 \\
20 \\
40 \\
17 \\
58 \\
80 \\
179 \\
77 \\
34 \\
150 \\
67 \\
86 \\
18 \\
98 \\
18 \\
137 \\
24 \\
14 \\
15 \\
62 \\
23 \\
16 \\
34 \\
184 \\
48 \\
667 \\
811 \\
78 \\
310\end{array}$ & $\begin{array}{r}474 \\
689 \\
188 \\
155 \\
90 \\
360 \\
54 \\
850 \\
334 \\
197 \\
374 \\
183 \\
138 \\
88 \\
685 \\
85 \\
766 \\
148 \\
98 \\
68 \\
298 \\
119 \\
67 \\
177 \\
468 \\
261 \\
2838 \\
1619 \\
202 \\
1487\end{array}$ & $\begin{array}{r}57 \\
83 \\
14 \\
18 \\
11 \\
48 \\
6 \\
102 \\
40 \\
28 \\
46 \\
28 \\
16 \\
10 \\
75 \\
10 \\
92 \\
17 \\
11 \\
8 \\
36 \\
14 \\
8 \\
21 \\
56 \\
31 \\
340 \\
194 \\
24 \\
171\end{array}$ \\
\hline TUTS & $81,861,50$ & 2,896 & 13,351 & 1,598 \\
\hline
\end{tabular}

1

Source: I. I. Valentine, Revion of Letifities, 1986-1936, I0bruary, 1987, p. 18. 
table glving the mames of the oolleges, thelr monotary alIotmonts, number of students alded, thoir 1934 enrollmonts, and thoir IIS quota during the sohool year 1935-1936. Of this group 278 (10.8\%) were candidates for college and nonprofessional degrees. In analysis of the students aided roreals the following:

TABIE 8

UIDERCRUDULTR COITEGE STUDRTIS AIDID BY RLOE IID SNT 1935-1986

\section{TABII 3}

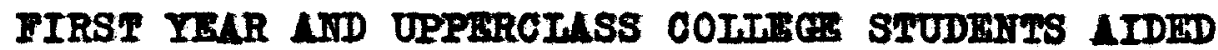
BY IYA III KHIUCKY, BY RLCE, 1935-1936 8

\begin{tabular}{|c|c|c|c|c|}
\hline $\begin{array}{l}\text { RLOE } \\
\text { minte } \\
\text { Iogro }\end{array}$ & Total & $\begin{array}{r}\text { TOPLT } \\
2896 \\
2621 \\
275\end{array}$ & $\begin{array}{c}\text { FIRST YRAR } \\
1236 \\
1117 \\
119\end{array}$ & $\begin{array}{c}\text { UEPTHRCIMSS } \\
1660 \\
1504 \\
156\end{array}$ \\
\hline
\end{tabular}

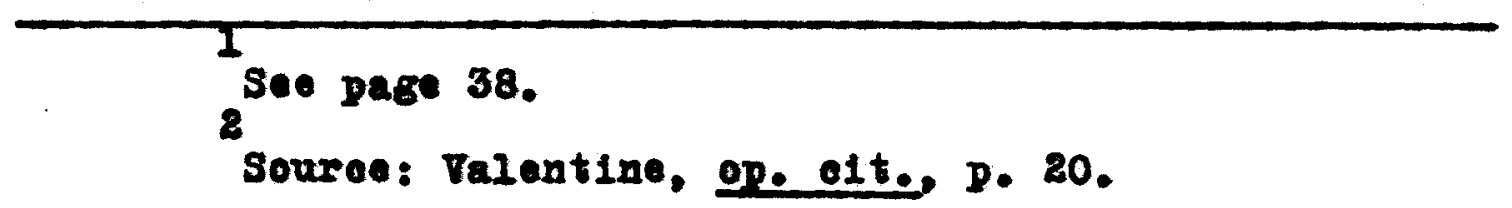


College Ifd in Kontuoky was reoeired onthusiastieally and got under way the first year with little diffoulty. Kontuoky newspapers, oollege offlelals, and the general pub210 Ielt oollege ald was a wise intestment of the publio funds. It was the opinion of Rev. F. Iowton PItt, Superintendent of Sehools of the Diocese of Ioulavilie that this help rexy definitely gent many etudente to college and kept then there who otherwise night nerex have had college train1 ing.

Graduate 11d.--Holp was givon a I1mited number of graduate otrdents who were unemplojed and who sought to complete the Yaster of urte or Doetor of Philosophy degrees. Candidates for other professional or graduate degrees were -ligible for assiatanoe under the College Mla program. The type of amployment, qualifloations for eliglbility, and method of payment were aimliar to those of College lid. First year graduate students could recelre as mach $28 \$ 25.00$ a month for thelr work and students dolng adranoed graduate study coula reoolve $\$ 30.00$ as a monthly arerage. As in college ald it wa permissible for graduate funds to be divided among more students than quotas oalled for. Iows that funds would be available for graduate students did not reach the two colleges which were elfgible for these allotments unt1l most of their shares of the noney had been used for under-

\footnotetext{
I. Iewton Pitt, in Eraluation of the Student Ald

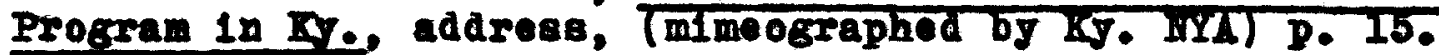


graduate mon and women. These 00110 ges were the Oniversity of Kentuoky and the Nostern State Teachers College. Funds for this purpose were given on the basis of the number of non-professional Masters and Dootors degrees granted between July 1934 and June 1935. In the sohool year 1935-1936 IYA assistance amounting to \$6026.39 was 81 ren 47 Kontuoky gradvate studente.

Elgh Sohool A1d.--Dae to the many sohool distriots in Kentueky whioh were eligible for III Sohool Ald and a shortage of olerical help in the high sohools this phase of the program got under way more slomly than the College and Graduate 11d. Quotas for each eligible high sohool were based on the rellel load carried in the community, the sohool census, and an estlmate of need from achool offiolals. Kantuoky was given an allotment of 6483 sohool aid jobs but by "epreading" pajments 9032 were actually alded during 1935-1936.

To be el16ible for Sohool aid etudents had to be eingle and between the ages of 16 and 25. Certifloation of the county rellef worker that the ohild's lamily was reeeiring assistance at firet had to aecompany application, but this ruling was relaxed to permit high sohool pupils to

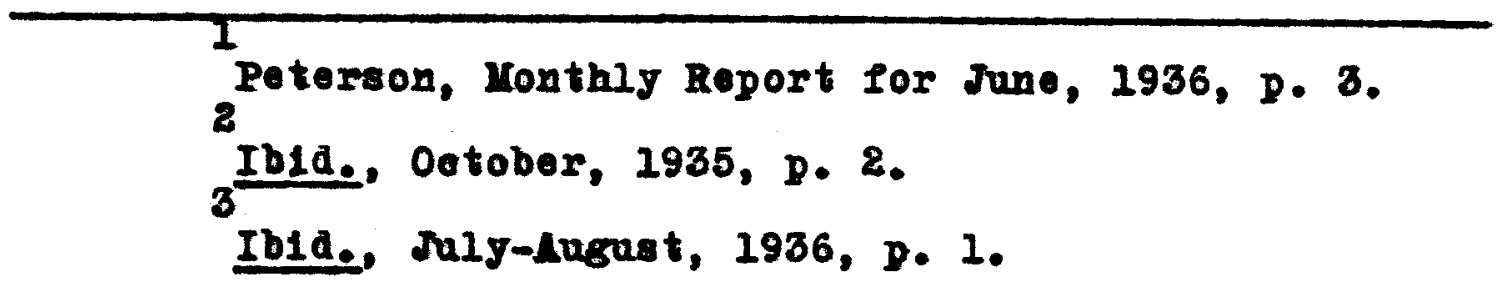


get IYA employment if their familles were ollgible for pub110 assistance bat had not been placed on the rellef rollo. Studente moeting all other requirements could be holped in grades seren and eight regardese of the organization of their sohool system on a junior and sonior basis. Students taking post-graduate courses in high sohool were eligible if preforonce had been given to undergraduate students and if the applioant were carrying at least three-fourths of the normal course load in aubjoets which he had not taren 1 previously.

Al sohoole lowerthan the college grade, both publio and private could partiolpate in the IYA program provided they were not profit making in oharaeter. Is with the 001 leges, the high sohools aelected students to recolve holp on the basis of qualifications set by the Fational Youth Administration. The torm Worthy student" was used in the requirements for eligibility, and it was assumed that youth from rellef families who were trying to romaln in sohool were "worthy" and should recelve assistanco. The prinelpals and superintendents of Kentuoky eocondary sohools made the Inal decisions as to which students should receive the funds within the allotment giten thom. From the beginning the rentuoky State Administrators omphasized the neoossity of carrying out projeots to emplog pupils reooiving IrI aid,

Tralentine, op. o1t., p. 22-23.


with assigmment on acholarship and need basis to be used only in rare instances. It first, due to the nowness of the program and the diffloulties of sotting up appropriate projeots, a large number of the grants were given for excellence in soholastio performance, but the poroentage rapidiy deereased as the schools were able to work out their projeots. By the end of the sohool year no more than three per eont of the jouth in sohool recolred help on a soholarship basis. The ruling that students oould work more than three hours on Saturday (prohlbited at flret) helped place the payment plan on an employment bssis. About two-thirds of Kentuoks ohildron lired in raral areas and attended rural sehools maling it neceseary for them to travel long aistances on foot, horsebaek or automobile to get to sohool. Those who took buses had to leare home early and at the ond of the day eatoh the bre immediately after sohool elosed, making it diffioult for some students to work the proper number of hours during the Iive sohool days. Itth the relexed Saturday raling they could aseemble on Saturday and werk contimuorely on any number of projeots. The state offlee empherized the ralue of the experienoe to be gained by the student in dolng his work at a regular time, aocounting for it by fllling out time roporte, and performing it in a satiafaetory manner. Schoole were urged to give work which would develep the native abllities of the youths or ald thom in determining a rooation which they might be 
selted to follow.

1

Torleing out projeots was a problen for the secondary schools whioh were ofton understaffed and hard pressed to give proper supervision to setting up worthwhile aotivi11e8. The state offloe asked that the work done should be maotally desirablo and. - . not lnolude those tasks which in the past have been done by otudents as a part of the personnel of the institution." Ordinary maintenance and janterial jobs and other routine aotirity that would be earried on anjway were not to be Ilnanced by IrI funds. Rocommendations were made in regard to projoota. Phese lneluded: elerloal work, llbrary work, chooktng student exere1ses, papers, and problems, poster advertising, work on sohool paper, care of athletio equipment, student safety guards and traffio directors, care of stage equipment, property and makoup, tutoring, aseisting in soolal service work, and condueting forums. For these services high sohool students were to reeelve not wore than $\$ 6.00$ a month for nine months.

The following Table shows the number of students ongaged in each of fourteen oocupations during the first year of IrIS Sohool ild in Kentueky.

\footnotetext{
I Peterson, op. o1t., December, 1935, p. 4.
$\mathcal{R}_{\text {Talontine, op. o1t., p. 24. }}$
} 
THET 4

IOSTBMR OF HICH SCHOOL STUDHITS BHCLOW

II FOURTATI III SOHOOL AID OCCUPATIOHS

II BATHOK DURTIT 1935-1936

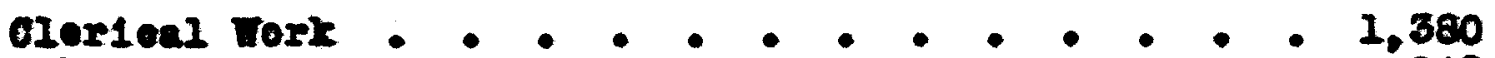

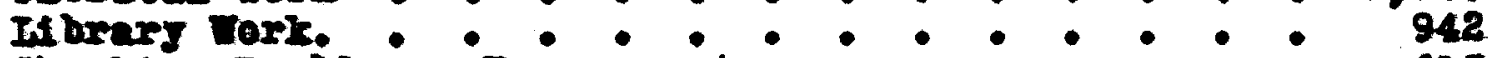
Oheolting Probloms, Papors, tto. : : : ! : 615

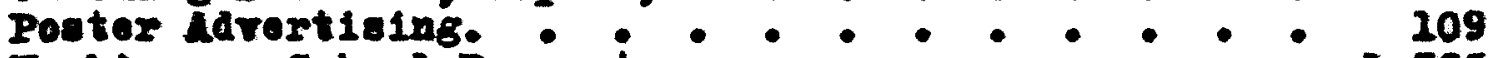
Forktng on sohool Property : : : : : : 1,825 Caring for Ithletio Irripmont : : : : : : 254 Student Safoty Caards, Traff10 Directors : : : 81 Care of Stato Bquipmont . : . : : : : : 66 Individual Instruotion ad Teaching : : : : 94 Inafatants in Cafotoria. : $:$ : : : : : : 328 Leatatante in Soetal Sorvioe vork. : : : : : 206 Iosiotante in Iaboratory. : $:$ : : $:$ : $:$ : 342 Ixtra Janitortal Servioe. : : : : : : : : 647 AI othore

Total - . . . 7,088

The final report of the Bivielon of Tinance and Statiaties for the year 2935-1936 howed that 9,032 atudents partiolpated in the Sohool all program with a total exponafture of \$294,827,84. In extra allotmont of $\$ 96,000$ had beon giten Kontreky because of drought maleing it poselblo to extend the state quota by 1,777 students at 86 per month oach for niae monthe. The additional funds brought the Kentuoky number of Sohool l1d untts to 7,888 whioh number

\footnotetext{
Souroe: Talentine, op. ofte, p. 25.
} 
was increased to 9,032, the aotual number of students aesiated, by the polloy of "apreading" funds.

In general it was felt that the Sohool ald program operated amoothly and mot with publio approval. The administration of it proved more alfficalt than had been thought at Iirgt, though sohool excoutires cooperated well. Drought, an Intensely cold winter, and the distances separating atudents from projeots and saperintendente from some of thoir oounty sohools, and teohnical problems such as the ease of students $117 i n g$ in one sohool diatriot attonding sohool in anothor, all wade the joar an erentrul and sometimes a tryIng time.

THE YOI-SCHOOI GOUP

The second large olassifleation of gouth to bo cerved by the Mational Youth Ldministration was the nonsohool group. Th1s body of young people was oomposed of both those who had completed high sohool or college and were unemplojed as woll as jouth who had loft sobool carllor and were unable to I1nd work. The age range for this phase of the program was from 18 to 24 jears. The procese of getting in touch with the out-of-sohool jouth was more diffloult

\footnotetext{
Poterson, Lonthly Report, July-Lugust, 1986, p. 1-8. 2

Frank D. Poterson, letter to Rlehard R. Brown, Lsalstant Dremtire Direotor, Hational Youth Ldministration, Tebruary 5, 1936.
} 
than reaching the in-sohool croup who were eselly reached through sohool personnel. It was necessary, therefore, for the organisation of the out-ol-gohool program to be highly refined and to be hondied by Intional Youth Ldministration officials from top to bottom. Is has beon shom ${ }^{1}$ the Kontroky adminiatration namod offlolals on a atato and distriot lovel to bring the work program dom to the ladiridual youth. Voluntary County Youth Counelis were also named to assigt the diatriot managers to nnderstend and to worl effeotitely wthin the loeal oommunitios. Whon work projeots were actually sot up there were added to the staff of the program in Kentuoky, projeot supervisors who remained with each looal work unit. The appointment of supervicors brought the Youth Ldministration down to the $1008 \mathrm{l}$ 10vel and beoame the Iinal link between the young people and the program.

It Ifrat it was proposed that inasmuoh as IrA was a part of the Worke Progress Ldministration it might be most coonomieal to place young poople on regular IPL progects on a auplementary besis to work one-third time, but in Konthery on 0otober 22, 2936 there wore still insuffieiont projeots to care for heads of familles who were firat on priority liats for exploymant with that program. On the other

Strex, p. 19-81.


hand, In Hovember, 1935 there were already over 8,000 mon and more than 1800 women between the agen of 16 and 25 onglojed on uPl projeote haring qualified for aseletanoe under that program. It became apparent, then, that VIL could not take care of aditional youth who were in need of and elfible for work relief. Woreeter there were 18,966 young mon betweon the ages of 18 and 28 in Civilian Conservation Coxps campe from Kantueky in the fall of 1935 .

It was learned by the Kontroky MIS office from County Youth Counosis and other sourees that in this state In addition to the projeote undertaken by other government ageneles there remalned a demand for recreation and commnity projeote, maio projeots, the construetion of playcoounds and swimming pools, manual arts projoots, hoalth and delinqueney aurrege, Improtoment of publ10 property projects, olerioel assistance in sohools and county and ofty offloes, rural library aervioe, and domest10 tralning units. Loeordingly the Jational Youth Administration offiee Issued to the Kentueky State Direotor a buletin setting up a standard for the development and operation of Fational Touth Ldminiatration roderal sponsored projoots. The four

\footnotetext{
Peterson, Konthly Report for Ootober, 1935, p. 3, and Wonthly Roport for December, 1985, p. 6 . 8 Ibld., Iovember, 1985, p. 9. Valentine, Op. a1te, p. 26.
} 
types of projeots recomended by the government weres

1. Projects for youth oommenity dorelopmont and reoreational leadership. This projeot was designed to provide parttime omployment of joung poople erom rolief families as leaders and assistants in the establighmont, organisation, and conduct of reoroational and commanity aotirity in plajground, ath10t10 Iillds, watersports areas, oamps, parks, community houses, Indoor reeroation conters, Eymnasiums, oommanity aotirity, arti and orafts, manual aotirity, and others.

2. Projoets of Rural Youth Development. To provide part-time omployment of roung poople from relief familles in rural oomminities in tmproving and beautifying sohool grounds, minor ropair of public bulldings, lding reforetation, alding the work of atate experimontal farms and agrieultural work; corelopment of county or commanity conters; spreading botter farming, sanitation and health practioes in rural commanities; rocational agrioulture; malntaining and onlarging varal Ilbrary eorv100.

3. Publie Servioe Projecte. To provide part-time omployment of young people Iron rellef fanil1es as assistants in Tarlous publio services to conduet activities outside the normal soopo of these looal corernmental agenoles, anoh as traffie oheols and control, cani tati on, health, and Investigation of looal and state governmental recorda.

4. Researoh Projeots. To prorido partt1we omployment of joung mon and womon from rolief fanilies in a varioty of 100al researoh projoots in local history, tex rocords, safoty ormalens, biologioal and agrientural oxporimontal aselstanes and other types of rosearch.

Wthin these broad limitations it was not diffoult for County Youth Couno1ls and distriot managers to dsoover 
beed for such projeets in most Kontuoky oommunities. To sot up projeot a Youth Counoll or ofvie agenoy realizing the need for IrI help eould aubnit an applieation to the atate III Director whose approval secured foderal support. In Kontuols the direoter usually oheored each projeot with the natlonal offloc bofore oneouraging the interested partios to begin work. Offiefally the sponeor of any of the four types of foderal projecte was the Hational Youth Maministration, but the ational gerernment reoommended atrongly that there be some publie organization or offloial, quasi-pablie, or a private, nom-profit agenoy to act as a cooperating aponsor. Iot only could the already established group lend adrice and eneouragement and opread laterest in the new enterprises, but they wore alao agked to contribute building apace, ut111t1es, or tools. Mlmost orery project in Kontuoky had a cosponsor and contributions from these soureos amounted to a alable pereentage of orerhead expenses. Stato IIIA D1reotors were expected to ueo $90 \%$ rellef jouth on work projecte and socure supervisors and other porsonnel noeded from the remalning $10 \%$ who were not required to be from families rooeiring publio assietanoe. Lotrally Kontuoky hired only 4.9\% of ite porsonnel for the work projeot progran Iron non-rellef persons, and secrered the other 95.18 of 1 ts peraonuel trom relief rolle. 1

Insd. p. 29.


51

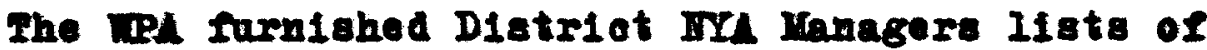
Joung porsons between 26 and 25 erom famillos on rollef. Fogether the IPA Aseignment Offleors and the IrA Distriot Uanagers seleoted jouths for the rarlous prodeets from these 11ats. IrL ald not affoot a family's elig1bility for WPL. Of the mones alloted each state for work projeots, the Fatlonal Fouth Adminiatration required that 61 per oont be spent on Commanity Derelopment and pocreational Projeots, 21 per cont on Fraral Youth Derelopment, 13 per cont on Pablio Sertioe Projecta, and 5 per cont on Researoh Projecto. Mlotments wore made to states in blanket amounte for a three months period and were granted on the basis of the rellef load in the state. To correspond with the allotment period projeots were set up on a three month's basis with estimates of the oosts of labor, supervision, and materials serving as a basis for the amounts given each projeot. The wace seale for projeet supervieors was llexiblo acoording to the security wage set for the oommanity in which the project wer under operation. Iouth oovld earn one-third the security were with a minimum of 36 and maximan of 46 hours worked eaeh month. In rontuoky 44 hours was the unf form roquirement. In no case covld a jouth carn more than $\$ 25.00$ a moth. 1

\footnotetext{
120 I01a., p. $89-30$.
} 
yany problems faced the state office in its attempt to aet the work projects. Distriet ranagers had to use woh initiative in doreloping 1deas, securing spossors, and Iitting the projects to the rarious commanties. Uswally the counties that had the highest rellef loads also had Iimited faellities around whioh projects might be centered, and the Inhabitants of suoh areas wore often unable to mare contribut10ns to the effort. In many rural distriots the jouths wore ofton widely seattered and wore laced with Inadeguate transportation. It would have boon less diffioult had aistrlet managers been ablo to set up like projecte in many count1es, but an effort was made to ift the needs of the local communitios nocessitating individual attention to cach project attempted. In addition most of the young poople arallable had had little training or experieneo and oould not be readily fitted into exiating organizations. MdninIstration afficulties in securing oomplete iste of elfgible young people, in getting registrations with the Hational Re-omploynont servioe and recolving proper cortification Irom the IPA office eren after projects had beon approved and allotments obtained plagued the state IIL staff in the carly peried of work projeots. IPL lssigmmenta to Irl wero -Ior In coming becakse of the press of other werk, and ofton Dletrlot lanagers had to rotrace their stops to elear away obstacles in getting workers assigned. Usually there was a considerable shrinkage in the number of youths assigned and 
those reporting especially as recerds were not always aochrate. Unt1l Jamary, 1936 . the projeet program was unable to gather wach momentum, but with the setting up of the new project proeedure by the foderal government at the first of the now year this phase of the irh program began to improve not oxly in Kontualy but in othor states as well.

By June 30, 1936 there were 208 projects operating in 208 counties. There were 9,316 Jouth workers and 390 supervisery emplojees. Of the youth employed 5037 were boys and 4279 wore cirls. The total expenditures on works projoots as of June 15, 1986 were $\$ 378,687.38$. The total estimated ralue of the work done as of June 30 was \$562,382.74. Table 5 shows the types, amount, and ralue of work aocompliahed by these projeots during the I1rst gear of IrI operat1on in Kontueks.

\section{IEOAO PLRTICIPLTIOA}

Irom the Deginning the polley of the Hational Youth Idminiatration in Fontuely wa to make no diserimination botween the white and Iogro populations. The rules gorerning eligibility, kinds of omplojment, worthy studente, and ethor

\footnotetext{
1

Sumra. P. 49.

Peterson, Yonthly Repert for December, 1985, g. 6-7 and January, 1936 Yonthly Report, D. 3, and Kay, 1936, p. 1 . 3 Peterson, Yonthly Report for Jane, 1936, p. 4-5.
} 
TUBTE 5

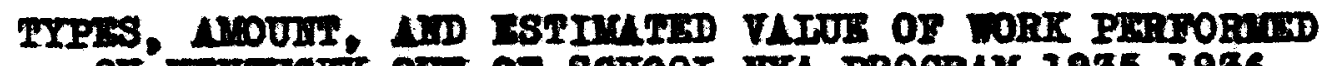

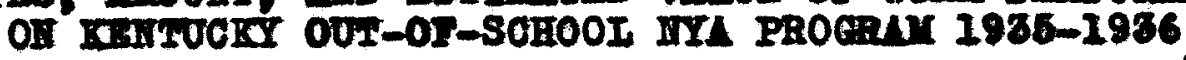

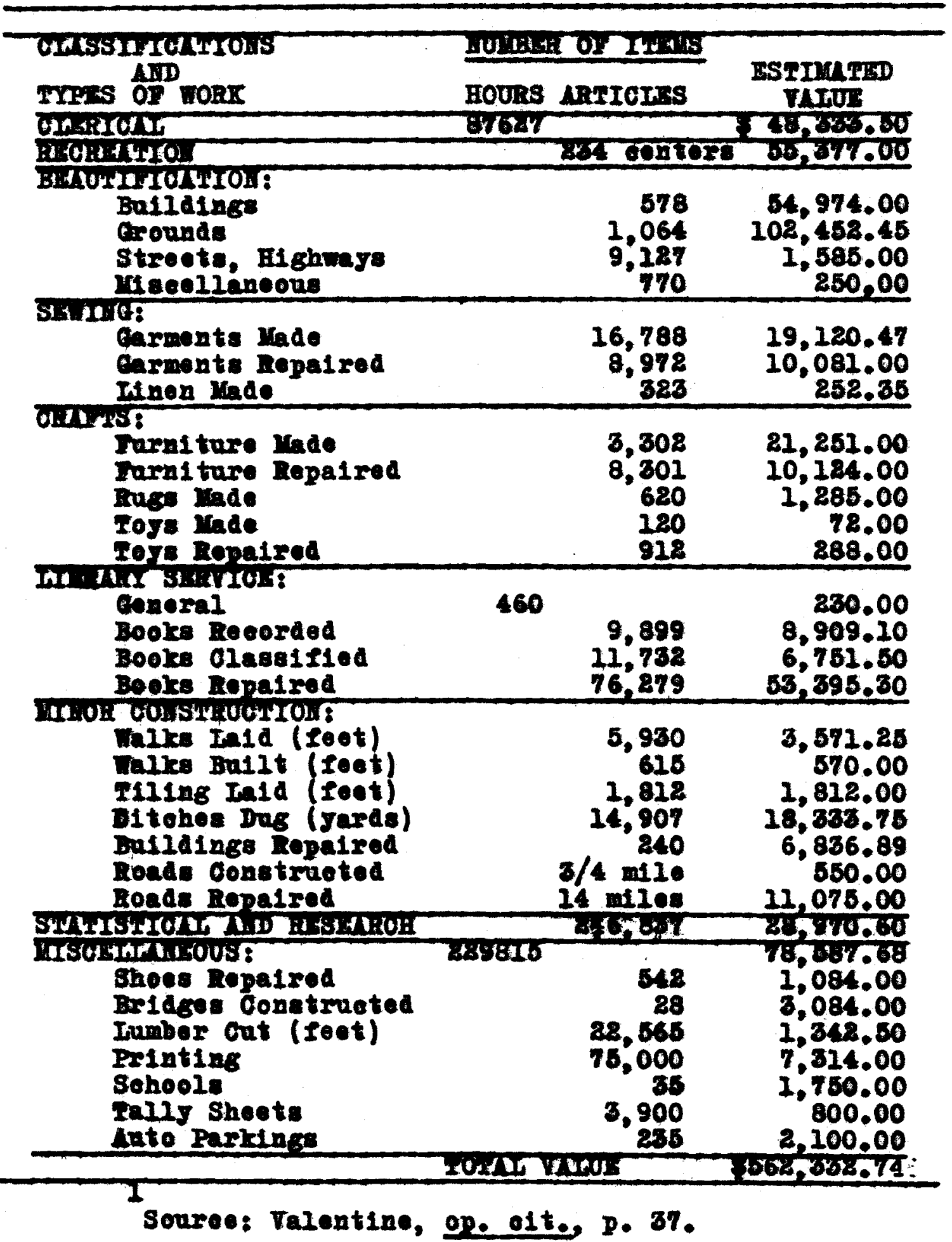


matters were identioal for both races. Ir. I. Willis Cole, Iregro editor, was placed on the state Ldrisory Counoil, and 14. T. E. Brown was appointed Lesistant State Direotor in oharge of Ilegro Letirity, whioh became a epeoial dirision of the state program. In Kontuoly $8.6 \%$ of the population is Iogro, and that group reoelred $9.4 \%$ of college uld giten in Kentuoly in 1936-1986, 9.08\% of Sohool 4 d, and $7.8 \%$ of jobs in work projecta.

VOGLIOINL GUIDANCE

Irom the first the Bational Youth Mdministration was Interested in serving the noeds of gouth for rosational counseling and training. Both the In-sohool and out-olsohool groups were reolplonts of this servioe. Several work. projects were sot up to study rocational problems in the state and to compile seores on intelligenoe and achieroment teste at the Dnireralty of Kantuoky. During 1935-1936 voeatlonal studies with the following t1tles wore made: "Waltrese, " Mrobaceo Induatry," and "Rad10 Serr100." 4 bulletin oalled "Whioh College Shall I Ohoose" telling brieng the currioulum effered by each of Kontuoky's $00110 \mathrm{~g} 08$ was completed. Wide diatribution was given these pamphlets. A egliabus, "Vooational Information for the Youth Counsellor and Culdance Worker" to be used in presenting a course in guldance to youth workers was drawn up, and a survey to show emplojment tronds in various oooupations in Kontuoky 
mes begun. Varlous men's lunohoon elnbs were interested in aseloting jouth with guldance and helped put on programs for a number of joung people's groups.

A s1x polnt educational guidanoe program was sot up for Kantuoky by the Iational Youth Ldminiatration inoluding:

1. A tril-time representative of guidanes should be plaoed in the State Dopartment of Bereation.

2. The recontig appointed comatiteo of the Kontuoky Lasoolation of Colleges and Secondary Sehoold ahould bo efflliated With the Divialon of Caidance of the Stete Departmont of Edueation. (ITM was Inatrumental in getting the Kontuary Aseoclation of Colleges and Secondary Sohoole to appoint a guldanoe committe0.)

3. Cutdanec oourses should be set up for beglaning teachers onrollod in the ColIege of Bdueation at the Onirersity of rontuoky and the state teachors' ool1eges.

4. Currioulum revision in Kentuoky high cohools should be made to inolude rooatlonal trainlag.

5. Cities of 10,000 or more population should harecalenanoe direator with a oounseler in eaoh sohool.

6. I branch of the Fational Vooational Culdane Lesoelation ghould be organized in Kenteery in ordor to bring this gerTloe wore elosely to the teachors of the state. (Lt the 1936 moeting of the Kontueky Bdueational iseodation this branch was set up. IrI was partiy responsible for this move.)

2

In June, 1936 a Junlor Placement Serv10e in Iouls-

Peteraon, Yay, 1936 Monthly Report, p. 18-14. 8

Ib1d.. p. 14. 
r11le was proposed and plans got under way for setting up an offloe where oounseling would be arallable for youths 18 or under and placement holp would be given older, unemplojed jouth. This service was to operate in conpeotion with the Irational Re-omployment Servioe.

$\Lambda$ enrrey of projeot workers to dotermine gaidance noeds was made during 1936 showing the arerage amount of sohooling to be 6 jears and 4 months. Of the 6838 workers cubmitting roports 94.4 por cent had no rocational training, and 62.44 por cont of those haring training got tholr skill from sohools. Ho occupational experience was reported by 53.3 per oent. Three hundred, Iffty-nine of the 6838 workere (4.78 per cent) had Iinlshed high sohool, 92 had entered college, and 3 had recolred degrees. By the end of the firat year 1t was felt that a start had been made on the problems of learning rooational noeds and socuring counseling and guidance for IrI jouth. The bulletins and mamals complled by IIS were arailable to all jouth in the state.

In its Initial year the Iational Youth Mdministration in Kontuoky got well under way. A sizable amount had

Iralentine, op. 01t., p. 47.
$2_{\text {Iold, p. } 46 .}$


boen acoomplished, and at the ond of the twelre months the program continued to wet general publie approval eapecially as roleod in the press. Interprotation of the alms and methods of the program had roached a large publio, and the stato adminiatration counted on improred oopperation and more effieient operation in the sooond yoar of ITI In Kontrooks. 
OHNPIBR III

THE IMTURITG PIRIOD, JUIE, 1936 TO JONE, 1939 
OHNPIHA III

THE UATURIIT PRRIOD, JUIR, 1936 TO JUIS, 1939

\section{Admiatration}

The pertod from the and of the inftial year of the Fational Fouth Adminiatration in Kentroky antil June, 1939, when IIL became a separate branoh of the Foderal Security usonoy and was no longer a wit of the Forks Progress Ldmin1atration, proved to be a timo of sottling into a program whioh already had roots in the ground, but which needed constant metohfulnoss on the parto of the Kontuoky administration to keop the intrieate organization functioning smoothly. to adjust to the ohanging natlonal rogulations, and to continue to hold the soodrill of the publie. As a contrast to the flrst yoar which meant the setting up of a brand new program in a rapid, dyamio Iash10n, jear two and those Immodiately following were 1088 draamie for the adminiatrators, but they reguired a different kind of oxeoutive skill as the publio had had timo to sit back and eraluate what had boes done. A great deal of interpretatite work was doze during these dajs as national and state offloials allke Illled requests for leotures on the IrI, and many pamphlots desoribing and explaining the Youth Program were Issued to 
61

Ghow what had happened to the money appropriated and to roreal that only fire per eent of expenditures were used for administratire purposes. I In general the jouth program was well acoopted in Kentuoky, and working relations with other ageneies in the state wore cordial.

In the summer of 1936 Irank Peterson accepted onploymont with the Kontuory State Corormmont on a part time basis but remainod Supertialng Direetor of Irh. Irom that t1me Robert Salgore, who had come on the staff in a full time oapreity, aseumed more and more of the dutiles of the director until in 1938 he booamo afrector in namo as woll as in funot10x. In the enumer of 1937 the Kentuoky Ldministratiro Staff lost three mombers, T. Aroh Bennett, Supertisor of Tork Projeots, Ot1s C. Anis, Suporrisor of Fdueational Lid, and T.C. Brown, Superviser of Jegro Letirities. The budget for state administratire purposes was out, and the vacaneles wero filled by placing two distriot managers in the state offlog and roluelng the number of distriots from six to four. 2x. Saljers felt that the faot that IrL administratire wage were lower than corregponding ones in IPL and the temporary nature of the Iouth Program probably aocounted to a large extent for the swift personnel turnover. These

\footnotetext{
Somo Faots about Touth and the IIS, (publishod by

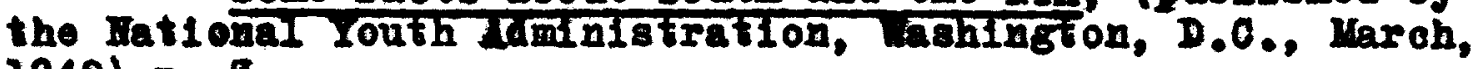
1940) $2 \cdot 3$.

See Fig. 2.
} 


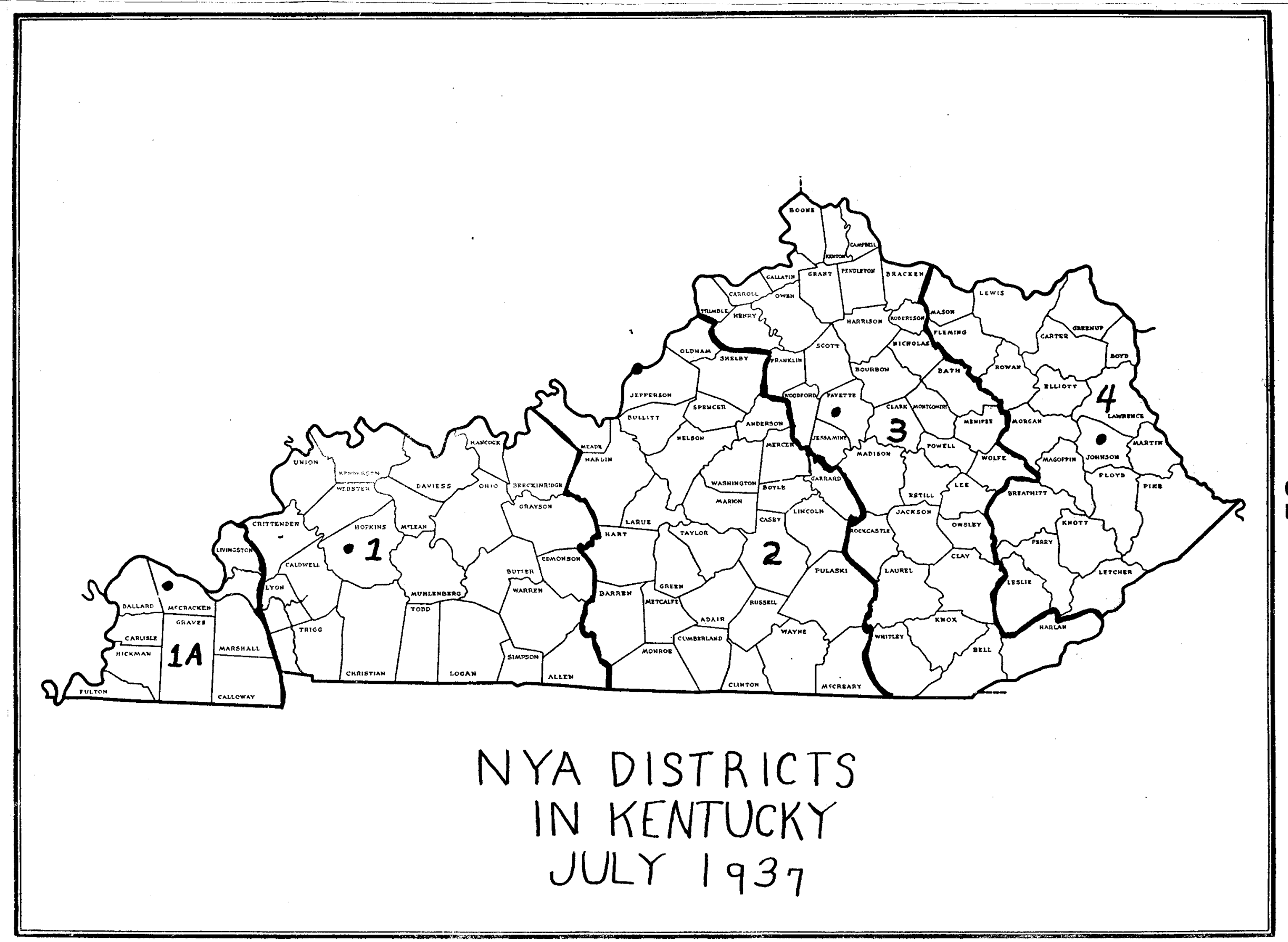

Fig. 2 
ehanges hampered the program. The four diatriet offloes were looated in unisonville (2), Padueah (1a), Iouiarille (2), Iaxington (3) and Paintarizle (4).

The diviaion of territory for adninistratire parposes remained in four distriots unt1l july 1, 1939, when a roorganisation plan made provisi on for eleven areas responsible alreotis to the etate IIL off100. It this time the state offlor was organised on a funotional basis along the same Ines as the national office with three prineipal dirisions, Operations, Imployment, and Finanos. It was thought that the new organization would bring state office sexvioes eloser to projects and should reavit in botter interprotation of the objectives and regulations to projeot supervisors. The Division of Operations was conecrned with the setting up and operation of out-ol-8ohool work projeots and the otudent worl program. The Director of this Birision was assieted by State Supervisors in the fielde of construotion, homemaking, arte and erafts, workehops, resident projects, and the atudent work program. The Direotor of the Diviaion of Fmploj-

\section{1}

Salyors, Report on the IYA Prosran, aubmittod in

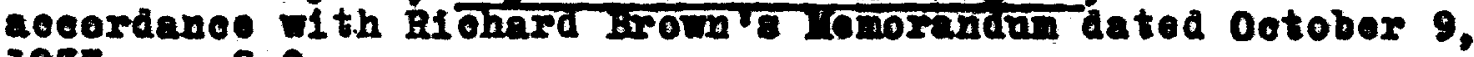
1937. P. 8-9.

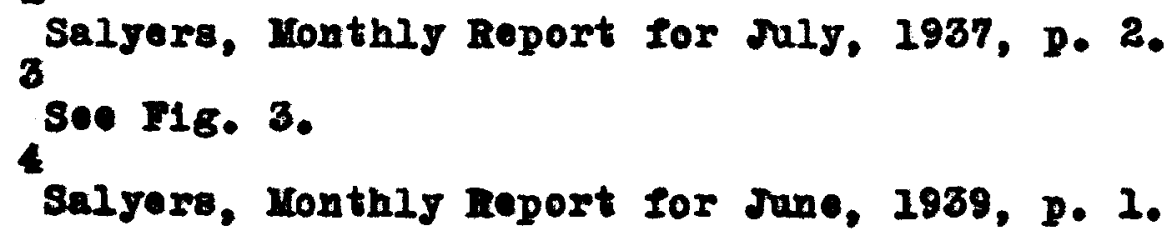


ment was assisted by State Supertisors in the flelds of oortifieation and assignment, youth personmel, and health and sanitation. This Diriolon was concerned with the oertifioat10n of elfgible gouth by 100 al referral agents, assigmment to projoets, reviow of youth working on projects, and all Group and inditidual guidaneo actitities. All sssigmments of out-of-80hool jouth workers were made by the state office Ditision of Enployment. The Dirision of Finanee was responsible for all finanolal aotirities, lneluding aocounting for funds, preparation of payrelis for all student and out-ofgehool workers from time shoots sent in from sohools and próJeets, and all contacts with the United States Treasury Locounts Offioe and Treasury Disbursing Offiec. MII III workers amplojed on the ont-ol-sohool projects program or the student work program, reoelred oheors malled by the $0 . S$. Freasury Diebresing Office in Iouigrille direotis to them.

In each of the eleten arese there was an area office In the charge of an Area Supervisor, who was responsiblo to the State Ldminiatrator for general polloles and to the D1reotor of the Dirision of Operatione for sotting up and operation of work projeote. In each area was a Personnel officor who handled all problems of cortifloation, employment, and revier of youth on projeets, and a Superrisor of Finanoe who anperTised the timekeping, aocounting, and pajment of workers.

Report of IrA for Kr.. Prepared for the Committeo on Rellef and unemploymet, largaret strong, Chairman, 1940, p.I. 
Direot eupervision of work projects was provided usually by project supervisers. The one or more sipervisers on each work projeot wore responsible to the Area supervisor for the proper operation of the project unit. There were approximately 250 projeot supervisors employed by the Kentuoky Youth Administration in June, 2939, but the number varied from time to time.

Ixpenditures for the period from Julg, 1985 through June, 1939 for IrIA in Kentueky totaled $\$ 6,500,429$. Of this anount $\$ 4,359,999$ was expended on the Out-of-Sohool Jork Program, and $\$ 2,140,430$ on the student Fork Program.

PROGRSS OF THE PROGR

Student Mid.--Imphasis during the period from Septomber, 1936 through June, 1939 in regard to the student lld program was largely on the carefal aeleotion and supervision of work projeots for reoiplente of IrI student 4ld. Ls adminiotration of the program was docentralized as far as possible, the attention of the state offloe could be placed direotis on essigting sohools and colleges in designing and carrying out appropriate student jobs. I national combitteo on Projeots consisting of ropresentatires of seoondery

\footnotetext{
1

I010.

Saljers, Faets about IYl in Your State, (mimeoeraphed by Kentuoky iMl and 188ued about Laroh, 1940) p. 2.
} 
sohools and oolleges aubmitted a series of resolntions whioh Kontuoky administrators sent to each sohool using III funds 1n the state. Distriat and later Aroa Yanagers urged tho incorporation of these avggestions into loosl programs. The national committee reoommended that lasolar as poseible projeots should be on the intellectual lerel of those employed and that all projeots howerer manial in nature should be 80 condueted and auperrised as to contribute to an attitude of respeet for honest work on the part of atudente and should be a souroe of disolpine in the derelopment of good work hablts and attitudes.

The oommittee further sugsested that oareful and broad planning for the projoots of the entiro oampus might be adraneed by formation of oommittees of faoulty, or of faoulty and students, to serve as adrisory or oren supervisorg counoils in evaluating projeots and in relating student intereste erowing out of worl on projeots to further opportunity for expression and derelopment. Proper supervision is of enprome importance in aobiering the real edueational ralues and attitudes for the students, and a partiolpating Inatitution hould realize the responsibility and obligation, oren with somo additional bugetary allowanoe, in proriding consistent and wise administration and aupervision of all

Saljers, Plenning rour Student lid Fork Program (almoographed by Kontuoky iri, Septomber, 1966) p. 1-L. 
Irational Touth Administration projeots.

In Kentueky the mothod of assigning Student lid rooiplents to work projects generally followed by partiolpating Institutions wo to request faoulty and edministrative offoors to aubmit a list of work projeote conneoted with their partioular departments or fields, together with deseriptions of the work to be performod. Kentuoky III Ldministrators reoommended that this prooedure be supplemented by aystemat10 exploration of both eampus and oommunity for other work of soelal usefulness and edueational ralue. After the program had boen in operation some time a list of nusultable aotirities for students was sont sohool offiolals which ineluded permanent imprerement of private property or furtherIng of private commeroial enterprise, replacement of other pald labor or carrjing on normal malntenence work ordinarily pald by the institution, work of a non-public, partisan, propagandistio, or seotarian nature, jobs involving the exerolse of institutional authority orer students, faoulty, or the general public, and researoh involving house to house or Industrial canrasaing. Occasionally projeots suoh as those mentioned abore were started, but it was necessary for such work to be eleared with the state office. Supervision of projeots was done by the head of the sohool department to whioh the student had boen assigned, by a faculty committoe 
aeleoted for the purpose, by apeolally designated students Irom the omployed group or by requiring submission of wookly or monthly reports of work acoomplished.

Throughout the 1936 to 1939 period a number of probloms presented themselves in conneotion with the administration of Student Md. Changes in tho program recomended by the national offloo or state administration regarding prooedure, quota allotments, and other phases of the program caued misunderstanding particularly on the high sohool Ierel. Lany rural elementary sohools and a fow raral high sehools in Kentuoky opened during July and the early part of Ingast. In 1936 speolal funds were avallable for early opening sohools, but these were out off the following year. The regular program did not get under way as a rule until late ingust causing somo confusion in the early oponing sohools. The faot that some students attended private ceoondary and paroohial sohools not loeated in the distriot of their realdenee (ospoolally mountain and llegro ohildren haring inadequate faoflities in their own distriots) caused some argamant as to whioh distriot commuters should be counted is in determining III quotas. In order to aerre students as justly as possible quotas were allocated to counties on the basis of relief loads and to distriets within counties on the basis of sohool oensus. Indiridual

$$
\text { Ibid.. 9. 10-11. }
$$


student applioations were used as the control and were oharged against the quota of the distriet in whioh the stadent resided. In 1937 to expedite aubmission of payrolls, prinelpals aubmitted timo reports for the Indiridual sohools in oontrast to the former praction of haring superintendents submit reports on a dstriet-wide basis.

Iach joar a meoting of oollege exeoutives in oharge of Student ald was held in Ioularillo whore problems related to the program wore thrashed out. Yootings of superintencents and prinolpels of high sohools wore conduoted in each distriot in order that information might be disseminated and sohool exeoutites might present thelr views and make rocommendations for the program. I yoarly bulletin followed by a summary of 1 ts major points was gent each sohool partiolpating. With the supplies of time reports a summary of payroll procedures was inoluded, and the first installment of oheoles also brought information as to how they should be a1spersed.

In assigning quotas on the basis of relles load somo Infuatioe inourred when a county had no oortifying agent for a timo. To adjust quotes to need, tho MY state offioe would hold baok from assignment as mang as 350 units of

Saljers, Report on IrL Program, Submitted in Looord-

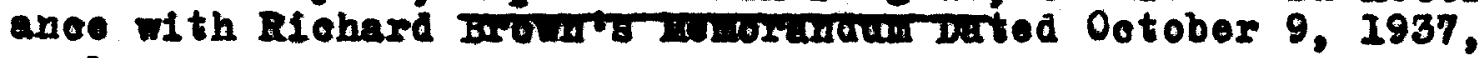
p. 1.

2 I010., P. 2-3. 
Sohool ul to be distributed later when aotual noed became moro apparent through student applieations. Is IrI got to be better know more and more students applied, many of whom wore not in noed but ranted to earn a little money. Sohool offlolals were urged to seratinize the family ineome figure carefully and dietribute jobs only when need was obrious. It was felt constantly by the state offioe that better work could be done if there were suffialent rands to proride a fell fleld staff to risit individual sohools and holp iron out in person questions whioh invariably arose as the ororam program was applied to indifidual cases.

From September. 1935 through December 31, 1939, 46, 871 Indirlduals had reoelred omployment through the student work program ineluding 36,673 recipients of Sehool lid and 10. 198 worling for College and Graduate Md. Between Julg, 1985 and June, 1939 the total cost of Student lid amounted to $\$ 2,140,430$.

The out-of-Sohool Program,--When the Ir/ program for youth who were not in sohool and who were seeking employment was effeotively begun in Jamuary, 1936 the major emphasis of the enterprise was giring rellel to joung people who belonged

\footnotetext{
1

Ibid., p. 3-4.

Repert on the Hational Youth Administration for Kentuok, avout laroh, 1940, P. 8.

Salyers, Some Faots about FY in Your State, p. 1.
} 
71

to needy families. Is the work progressed, however, training for rooational placement beoame the ohiof alm of the adminlstratore of the program. Helping young people to foel they had a use and a place in soolety was also an early goal. During the 1180al jear 1936-1937, IrL projeots operated in 207 of Kontuoky's 120 count10s and oupplied part-time omploymont to 14,056 jouths. It any one time approximately 7,000 white and regro workers were engaged on about 320 projects. Ioeal conditions largely determined the number of hours worked and the rate of pay. There were four wage elassifieations used: unskilled, intermediate, skilled, and profeselonal and teohnical. The work month ranged from forty to Ilfty hours with workers allowed to stay on the job more hours in seotions of the state in which lower hourly wage ratea prevalied.

1 major problem whioh made 1 tself apparent in the -arly jears of the program and continued to plague stato administrators was secraring adequate project supervisory personnel. The rariety of funotions required of appervisors included not only profletenog in the skill necessarg to a000mplish the work, but the ab1lity to denonstrate and assist joung untrained persons in the learning and performanee of that skill. Furthermore aupervisors wore expected to

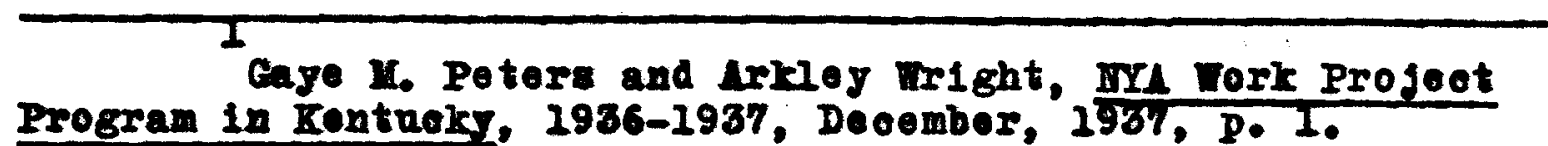


exeoute the wechanical and elerical features of their projects, plan the work, and keop socarate records of the exoups' acoomplishments. IrI also hoped that these persons would give counseling serrices to workers. Irequently in monthls reports to the Mashington off100 the Kentroky Ldmin1atrator remarked that inadequate oupervisory personnel hampered the program. Salaries were 10w, and in the constant tarnoter of inoumbents the best qualified persons seemed to 1eare. To help train persons for supervision three day institutes were held at interrals in rarlous portions of the state, and manuals woro distributed regularly to keop superTisors informed of their job requirements.

In addition to learning the use of some marketable arill while omployed on an IrIA project jouth workers were giren the benefit of a number of other services. Bulletins deserfbing raplous roeations and the opportunitios for their practioo in Kentuoky were mimeographed and distributed frec of oharge. "Career Conferences" wore condueted during whioh leaders of oocupational groups addressed youth workers and answered questions both in tho eroups and privately if des1red. There were study olubs partloularly omphasizing health measures. The Imerican Red Cross conduoted courses in First 4 d, and loctures and motion plotures aoquainting

\author{
Io1d., p. 3 . \\ Saljors, Report on HYA Program, p. 6.
}


the young people with the dangers of alsease and the importance of proteotive diats and santation in healthful 11 ving wore shom. In some instanoes ITA offleials were ablo to gecure Iree or at cost medical aerrioe from publie health offloers or from dootors partioularly interested in tho Youth Program, Thorough medieal examinat1ons, Immunizations, and treatmonts wore secured for many jouth workers.

Supervisors were instrueted to be alert to employmont opportunities for youth in prirate industry and rooommend their workers for jobs eren though they be temporary or ecasonal in charaotor. Usually it was possible for joung people with positions lasting only a few weoks or months to be rooertified for IIA projoets at the end of their employment under pritate ausplees. Reereation for the joung peoplo was reoognized 28 important, and many reoreation faollit1es wore used by the joung people who had built them as well as by other mombers of the oommanity.

From the beginning the problem of eortifying gouth workers and assigning them to projeots was diffioult to manage satiafactorilJ. During the period that IIA was a part of the Works Projeots Administration cortifloations from all sources had to come through a county cortifying

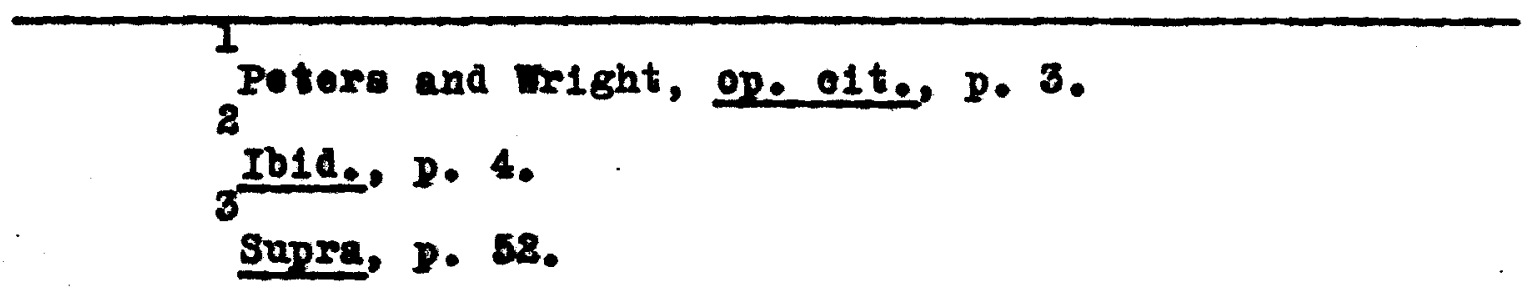


agent enployed by the fiacal oourt and approved by the WA Dirision of Bmplojmont. There were alwage a number of counties in Kontuoky that had no oertifying agent. Where tho WPL load was high in a county thore was a tondenoy on the part of the IPA Distriot Offices not to aoopt oertifications for III emplojment. Frequently there were a largo number of certifleations for IPA in a county, where there had never been a comparablo number of liYa cortifieations. In some instances there was a difference of opinion with respect to the philosophy and objeotires of IYL botween the offloe of IrI in Kontuoky and those responsible for making certifioat10ne. There was good oooperation, howerer, botween the state WPL off10e and III. Beeause of the lag botween the polloles of the state WR office and the aotual performanoe In the oounties or distriots maleing up that program, many counties badly noeding IrA recolved praotioally no cortiflcations in the early years of the IrA work program. It was desirable Irom the point of vien of the Iry for there to be a arrplus of cortified youth in order that roplacoments on the projects oould be offoeted epeodily. There were nevertheless instances when the number of youth bolng certified was not large enough to make noeded replacements on operating projecte. The problom was not solved until the wPA and IrI

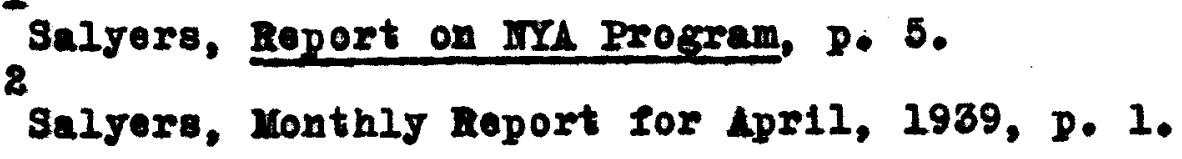


programs became separate and the Youth Program was pormitted to make 1ts own certifications. The hiring of an ITI Strpervising Soolal Worker to assist in applying atandards for certifleation also helped ease this bottleneck in the pro1 gram.

In the early gears of the work program construction projects suffored from laok of teohnieal adrioe. Ls conatruetion was usually minor in nature the co-sponsors, who applied housing and utilities, would not employ arohiteots, and sometimes the plans arame up by the oo-sponsor and the III expervisor were rather orude. For sereral jears thore was no one on the Kentuoky IrI atafe who was technieally trained in connection wth oonstruetion projects, and it was not always possible to secure proper assistance from other courees. By 1939 a trained Supervisor of Construetion was plaeed in the Division of Operations and arohiteotural asalstance was avallable to projects in the state.

During the period Irom September, 1935 to June 30, 1939 the Out-of-Sehool Work Program employed 24,974 young people in Kentuoky. The major acoomplishments of this group

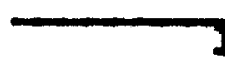

Salyers, Lonthly Report for Lay, 1939, p. 1. 2

Saljers, Report on IrI Program, p. 7

Report on the Hational Youth Ldministration for rentuck, Tproparce Ior tho comitioe on HoIreI and Unemplojmont in Kontuoky by Iational Youth Ldministration for Kantuoky, about Jaroh, 1940) p.t.
} 
Ineluded:

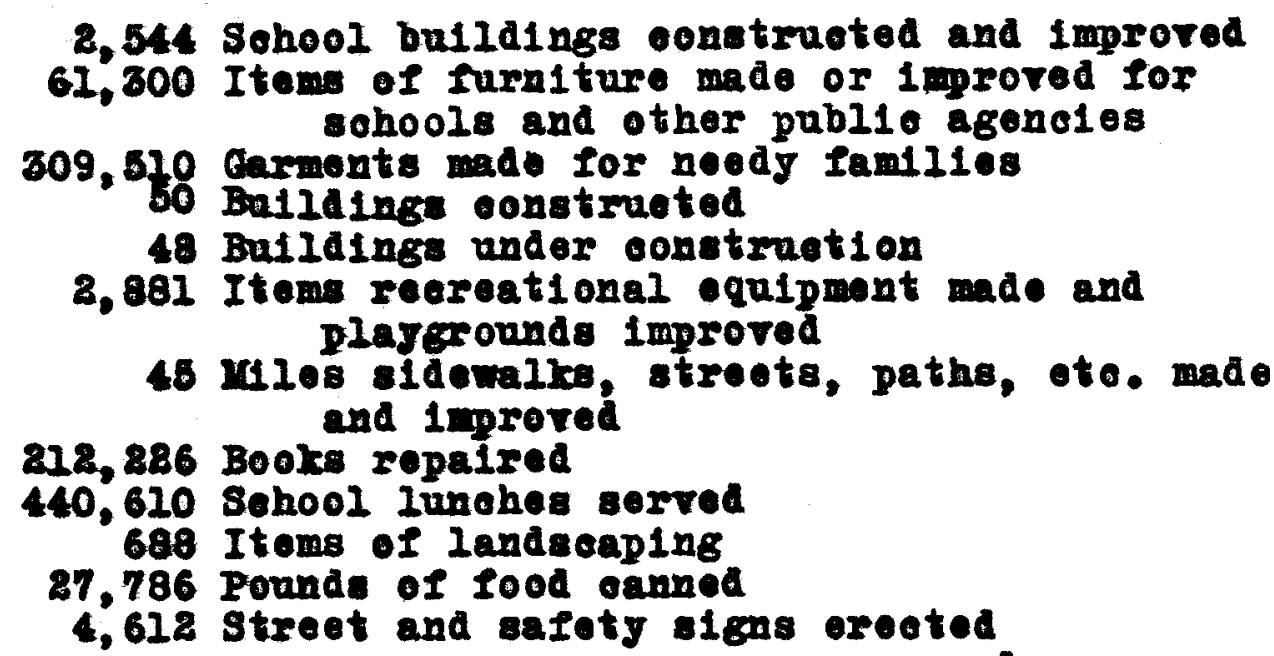

\section{1}

Toeational Galdanee--The Innotions of the Iational Youth administration were not limited to proriaing student L1d and part-timo omplorment for out-ol-8ohool jouth. Whe underlying objective is that of helping jouth emplojed under the program to beoome adjusted to the goolal order of whioh they are a part, stated the 1937 Coidanes Iamal for the nse of IIL Projeot Suportisors. Le a means of reallaing that waderlying objeotive IrI work project supervieors were urged to protide gatdance and counseling. The guldanee effort we broken dom into five divisions, social, physieal, character, adueational, and rooational. In order to apply rnowledge in these areas where it was most needed projeot supervisers rere expoeted to talk personalig with eaoh ind Tlenal jouth to learn his interests, make a commanity aurvej

$$
\text { Ib1d., p. 1-2. }
$$


of oooupationl trends, and organize a program of oooupational alsonssion groups. To assist supervisors in this phase of their jobs literature lists in the guldanee f10ld and carerully dotalled manuals as to procedure wore supplied them. A follow up card was to be kopt on each youth to ghow progress or failure, where he went after learing BIM, the lind of job reeclred ineluding emplojer, wages, hours, and adjustmont to privato industry. Supervisors were asked not to neglect cultural and sooial aspeots of living in their contaots with the jouth workers.

The state office contimued to supply both project workers and sohools recelring Student Ald with rocational atudies of rarlous oecupations open to Kontuoky youth. Goidance institutes were oponsored by projeot supervisors or interested mon's servioe olubs. Diacrssion spoups did not IImit their thinking to veeational atudies alone but talked about such related matters as personal appearanoe and hosith. In g1rle" projects disoussions of homemaking and meal planning were popular.

in annually rerised bullotin entitled What College Shall I Choose" was lasued Tra youth. This bulletin do-

\footnotetext{
Galdanoe Yamaal for the Doe of III Projeot super-

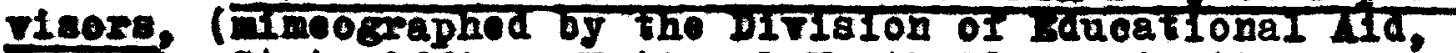
wntuoky state Office, Iational Youth Mdinistration, Iugust, 1987,) $p_{q} 1-10$.

no1d.
} 
soribed briefly the ourrievin and sallont foatures of each of Kontuoky's colleges. Cl0se contaot was kopt with the Fational Re-Inployment Servioe and later the Kentuolcy State Employment Servioe and the Onited Stater Imployment Service in an effort to place as many young people in full time private jobs as posaible. In Ioularille Junior Placement and Counseling Division of the Kentuoky State Implojment Servioe was aponsored and Inanced by the Hational Touth Ldministration for Kentueky. In the first $81 x$ months of 1937 the Junior Division intervioved 3203 individuals in 3656 interriews and had plaeod 619 of these in pritate industries. Junior Placement Serrices were begun in Covington, Iexington, Frankfort and in other Kontuoky toms shortiy after the Iouisville projeot got under wy. Once the need and effeotireness of Junior Bmployment Sertices were establiohed the Iational Youth Laministration axpeoted to turn orer this funotion to the Kentuoky State Rmployment Servioe. In addition to the new guldanoe aims throughout the period from 1936 to 1939 Kontuoks III continued to urge the earrying out of the goals aet up for rocatlonal guldance in 1935.

Ipprentioe Training,-mrom tho beginning administratore of IYA felt that one way of helping youth adjust to

Flret Lnuval Report, Ionieville's Junior Placement and Counseling Division of the Kontuoky State Employment Service, September, 1937, p. 3 . 8 See page 56. 
twentifth contury living was to provide in as mang comennit1es as possible apprentioe training for those persons interestod in learning highly skilled orafts. In 2934 an Apprentleoship committee for the state of Kentueky was established under the program of the National Industrial Recorery Lot. This committe dereloped a state apprentioeship plan, but when IIRA was declared unconstitutional, the committeo cossed to Iunetion. The Kontuoky Youth Administrators and the State Inglojment Servioe became interested in reriving this plan and invited a representative of the Federal Approntioe Comittee to oome to rentuoky to assist in sotting up a program in the atate. Through the influence of BSIS and FIA the Kentuoky Governor appointed a State Lpprentioeship Comnittee to draft a bill providing sutable logislation for the derelopment of apprentieoships in the stato. ISIS prorided personnel until the bill appeared before the Kontuoky 1

10gislature. Students in the University of Iouisville Iaw Sohool reoeiving student Ald drem up the bill. This Iegislative program failed to seoure an enactment of a state aponsored apprentico program, but the interest in the ondearor did not dieappear. Som of the IYI sponsored mochanieal projects wore vers nearly apprentioe training shops, but lacking a definition of apprentiooship by the Kontuoky state

$$
\begin{aligned}
& \text { Saljers, Yonthly Report for July, 1937, p. 6. } \\
& 2 \text { Salyers, Uonthly Roport for Deoember, 1937, p. Z. }
\end{aligned}
$$


Iegielature Ira for Kentuoky dropped the Ieature "Ipprentice Training" erom 1ts program though oontinuing to oponsor maohine shops. 1

Resident rork Centers.--lnother type of IMA program for out-of-sohool youth in Kentuoky in addition to the work project enterprises was begun in the spring of 1938. This feature of the program was the resident work center to which jouth were mored from their home commenities to gain work experience and related training. Some centers prorided aeademlo training similar to that in the socondary sohool and junior oollege. Osually there were extra-ourrieulum aetirities such as athlotio teams, nowapapors, student oounoils, and secial affalrs for the 18 to 24 jear old jouths. Is a rale jouths at resident centers earned $\$ 25$ to $\$ 30$ a month by part-time work. After paying subsistenoe costs, each had $\$ 8$ to $\$ 12$ a month for personal expenses.

Kontuckg Youth Idministrators began feeling out oollege offloials and work projeot emplojees in regard to establishing resident work oenters in the state in December, 1937. It was deoided to work slowly at IIrst. Clearing

\footnotetext{
Taljere, Wonthly Report for Waroh, 1938, p. 2-3. $_{2}$

Paul B. Jacobson, Youth and Work Opportunitieg, (Reprinted from the Bullotin of the Hetronal isedation of Secondary Sohool Prinelpals of the Hational zaucation ls8oclat10n, Lpri1, 1940) p. 114-115. 3 Salyers, Mouthly Roport for Deoember, 1937, p. 1.
} 
81

mage rates with WPL delayed aotion, but the eirst project for resident workers was opened on lay 1, 1938 at Carrollton, Ky. Interested jouth omployed on work projects were reforred to Carrollton from all distriots in the state until the desired number of about 100 reported. There were difloulties at I1rst, and the Lasistant Supervisor of Work Projeots assumod direot oharge of the project during Jane. BJ the end of the month, a definite olass sohedule was oompiled and minlmum odueational and training requiroments were established for resident youth. The rooatlonal training program was sot up with instruotion in throe areas, eloctrieity, auto mechanies, and general shop work. Faoh youth was required to take ten hours per wook inatruetion in one or another of these areas and an additional five hours per weok instruotion in academie subjects. During June the youth exeavated 300 yards for an underground power 11ne, conetrueted a tool room, offico room, and remodeled the workshop and auto wohanios workroom. In the workshop work benohes, tables, Ille desks, and other 1 toms wore made for use on the project. Recreational aetivities and a library were provided the boys.

4 realdent projeot for Ilegro mon was opened in September, 1988 in cooperation with the Kentuoky State Industrial College at Irankfort. A fow part time resident

Salyers, Monthly Report for June, 1938, p. 6 . 
projeots where youthe remained two weeks and roturned howe for two weoks each month wore begun in the state. Expenditures.--Dpenditures for the entire Hational Youth Ldministration in Kontuoky inoluding Student Lid, the Out-of-sohool Programs, and the other phases of the aotivity wore as follows:

September, 1935 to June 30,1936

July 1, 1936 to June 30, 1937

July 1, 1937 to June 30,1938

July 1, 1938 to June 30,1939

July 1, 1989 to December 31, 1939
$\$ 1,501,662.47$

$1,074,622,41$

$2,301,606.68$

$1,894,397.25$

$969,500.11$

$7,780,688.92$.

\section{FIOOD REIIEF ACTIVITIRS}

The Ohio River flood of Jamuary and Fobruary, 1937 affeoted five of the six IIA distriets. Lost affoeted wore Distrlot 6 whioh ineludes Loulsrille, Distriot 1 inoluding the western Kontucky counties, all but one of which were affoeted by the flood, and Distriet 8 whioh inoludes counties along the Ohio Riter and those in the rielnity of Cinolnnati. Seroral counties in Diatriets 2 and 5 more direotly affected by flood waters, and practically orery county in each of the two distriots harbored large numbers of refugees from flooded areas. On Jamuary 21, diatriet offlees wore author-

\footnotetext{
Saljers, Monthly Report for Horember, 1938, p. 6. 2

Report on the Hational Youth Administration for Kentucky about laroh, 1940, D. 1-2.

See F1g. 1.
} 
Ized to cooperate with agenoles ongaged in flood relief work, and on Jannary 22 a meeting of supervisors was held in Jefferson County to discuse assignmonts for helping this area moet the orisis. Hajor Noville Miller of Iouigvillo was offered the gervices of the entire IYL State Offioe Staff and of project workers and supervisors in Louisvilie and Jefferson County. Radio oalls resulted in the mobilization of hundreds of oollege students nearly all of whom were assigned to olerioal and ollnio work, and continued their duties throughout the oritioal period. Diatriot and county Supervisors throughout the state marshalled their IrYA forees to assist in rellel work, resouing poople and stook from the Ilood waters, construoting and equipping refugeo conters, traneporting lood, fuel, and olothing for relugees, building tomporary offloes, walks, roads, and bridges, assisting health officers, physielans, and nurses in the inpooulation of thousands of refugees and others against typhoid, assistIng in foeding oenters, in oloaning and ropairing water mains, and in repairing telephone lines.

is soon as the Red Crose established offioes in Loulsrille, looal ohapters were authorized to furnish materlal to IrA sowing projects for the produetion of elothing for flood atrieken families. Altogether 6,500 projeot

Report of Imergeney Flood Relief Aetivities, January and Fobruary, 1967 of the lational youth Idminletration

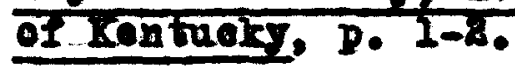


workere and expertisors and approximately 3,000 student 4 id reeiplents were ongaged in emergeney work throughont the stato. By Fobruary 6 the water had subsided suffiolently to -nable the state office ataff to roturn to its regular offico at IInth and Broadway in Ioularille after an absence of two wooks. Work began immodiately on the job of making up for the time lost from the regular prosxam during the 1lood. in omergenoy flood appropriation whioh enabled IIY in Kontuoks to aid an adifional 2,913 students was allooatod among oolleges and h1gh sahools whose students were affeoted direotly by the flood. The additional funds prorided part-time emplojment for 2,085 high sohool pupils on the basis of a $\$ 6.00$ monthly arerage and 828 00llege students at $\$ 15.00$ per month.

\section{TROMDS}

As IrI in Kontuoky matured through the 1936-1939 peried cortain trends wore observed. There seemed to have grown an increasing reoognition by sohool offleials and oommanity leaders of the problems of young people who had dropped out of sohool or who had finlshed sohool and were unable to secure jobs. This development was resulting in

\footnotetext{
1 I01d.. p. 1-10. Kentuoky, P. I.

Ira Chrodiele, Tol I, Jo 1, Maroh, 1937, Louisville,
} 
efforts for oloser oooperation betwoen IrIA and the sohools for the beneflt of out-eI-sohool youth. In 1 ts first jear IrI opereted a large number of projeots for ropair and Improtement of sehool bullaings, but these gare way almost entirely to projeots for the construotion of sohool builaings. Other small projects were alosed and offort was made to oarry out fowr bat larger undertakings. With the relatively small amount of funds avallable larger projeots offering a rarlety of work oxperienoes seemed the beat investment. Fesident and semi-resident plants made the servioes of IrA arallable to jouth liring in 18olated communities.

Tmphasis oame to be laid on setting up projeots that would train youth in skills wioh offered possibilitios for lecal emplojment. Continuing efforts were made to acoure trained supervision for projeots. Group guidanoe and related training were made a definitie part of each projeot. orten Ira had to develop its own program in this area as comminity resourees were sparse. In 1938 a state-wide program of health examinations and health edueation for all -mployees on out-ol-Bohool work projeots was begun refleoting the growing oonrietion of state youth administrators that partienaris in $10 \mathrm{w}$ 1noome groups, poor health 18 ofton a reason for labbility to obtain work. In contrast to

\footnotetext{
Report on the Rational Youth Ldministration of Kentuok, about laroh, 1980, P. 4-5.
} 
the flrst jear the number of hours and conseguent monthly earninge of workers on out-of-sohool projeots inoreased considerably as the program went forward. In the lowest bracket jouth employees reoeived twioe as much work and earnIngs in 1939 as they did in 1936. It was Ielt by the admin1etrators that the IrA projeot work should more nearis approaeh fall time employment than peraisted even in 1939. Flexible and experimental the rational Youth Administration had proved that it could be adapted to sorre a variety of gouth needs. The Youth Program looked forward to changes of many kinds as the United States mored into a defense and finally a war perlod. 


\section{CHAPTHR IV}

THE ILTIOULI YOUTH ADUINISTRATIOI II DETHISE LID RAR 
OHAPTHR IT

PHE ITATIOILC YOUTH ADMINISTRATION III DEFEISE AND WAR

\section{Adminletrative Changes}

Frem the time the Irational Youth Administration becamo a soparate unit Irom the Work Projeots Ldministration in the Federal Seenrity Lenoy in July, 1939, antil July, 1943, when the Youth Adminiatration ceased to function, there were sereral Important ohanges in the organizational ploture of IrI on the national and on state lerels. There wore changes in the philosophy behind the adminlatration of the program whioh reflected thomselres in the operation of IrA, in 1 te produote, and in the publio attitude toward the program. Both organization and philosophy were affooted vitally by the defonse period, the ooming of world war II, and the oonooquent Industrial boom. Beginning as a phase of national rellef in 1935, the FIC mored from the alms of equalizing edneational opportunities and providing fobs for unemployed jouth to a goal incorporating these runotions but adding the objectire of training young people in industrial skills that would be eseential to national defonse. There were times Irational Youth Administration Annual Report for the Year Ending June 30, 1940 (prepared by the Dirision of F1nance and Statistios, Washington, D.C., 1940) p. 53. 
when it appeared that III seemed to be conduoting a sohool program for projeot emplojees as there was littlo evidence of tangiblo produotive aocomplishmont, the hours of socalled work were short, and a considerable amount of instruetion not essential for produetion was provided on paid time. In 1940, however, the IrI tightened up its program and began ompasizing produotion. Instruotional aatirities not directig related to production were eliminated from paid time on the work projeote, and it became the intention of the national leadership of the program to make it a work program in every sense of the word. Imphasis was still placed upon training, but upon training on the job through intensive produotive activity under careful supervision. Th1s plan was in keoping with the primary funotion of proviaing exployment for unemployed beginning workers.

Beginning July 1, 1942, the out-of-sohool program became the IrIa Var Produotion Training Program whioh propared joung poople, 16 through 24 years of age, for jobs in war iadustries. Onder this system youths were taught only those sk11ls termed essential by the Tar Lanpower Commission and at the same time produced huedreds of Items required by

\footnotetext{
Touth and the Tuture, The Cenerel Report of the Imorioan Youth Vominision, Jphblished by the Imerican Coun011 on Fdueation, Washingtion, D.O., 1942) p. 64-65.

IrI in Martime, (pamphlet published by Fra, WashIngton, D.0., about January, 1942) P. Z.
} 
the nation's armed servioes and other publio institutions.

In the 1939 to 1943 period an important ohange came about in the relationship of the IYA out-of-sohool program and the public sohools. Nost IrIA work projects were conduoted on a part-time basis in order to inolude as many unemplojed jouth as possible. Is the noed was olearly evidont, many individuals and groups urged that an additional part-timo educational program be provided for youth on the projoots. In a fow instanoes a part-time oducational program was prorided by the sohools, but not all sohool authorities were ready to face the problems of out-of-sohbol youth in a coperative way, and Inanelal inability to help was almost a unitersal problem of the sohools. Becanse of the diffloulty of getting aohools to sot up oooperative oduostional opportunities for IrY bogs and girls on work projeots, prorision for part-time oduoation was made in some Instances by the IIIA. The provision by ITA of a looal edueational service, eren one limited to project workers and on a part-time besis immediatelg gare rise to contrororsy. Finally a compromise was made in the form of an agreement signed July 27, 1940 betwoen the administrator of the III and the United States Commissioner of Bdueation, in which 1t was agreed that state departments of eduoation would

Salyers, Mffectire Use of the Mra Program in Total vobllisation for the War Iffort," (mimeographed by IrI for Kontuoky, Fobruary, 1942) p. 4. 
assume responsibility for developing sutable educational programs for the youth on IIIA work projects, and the IYA would abstain from providing suoh programs. In ootober, 1940, Congress appropriated runds to be adinistered by the United States Offloo of Bducation and to be ganted to the states for "related or other neoessary instruotion" under publio auspioes for youth on IrYA work projeots.

During this period of ohange in the philosophy and administration of the national program, MYA in Kentuoky rellooted these varlations in adminlstrative ohanges within the state. In July, 1939, there were eleven Areas and Area Offioes in Kentuoky. Due to oentralization on the part of the state administration and a reduetion in the number of projeots (a national reoommendation) the number of areas was gradually reduoed to four in Julg, 1942. At that time the state TYA offloes were Ifquidated, and the United States was drided into 12 reglons oomposed of sereral states each. Kentuoky was placed in Region V With Wlohigan and Ohio. Mr. Orin W. Kaye with offioes in Cleveland, Ohio was named Reglonal Direotor. All fllos were trangforred to the Reglonal offloe, but were kept separated acoording to states.

\footnotetext{
Youth and the ruture, Coneral Report of the Amer1oan Youth Commiss10n, p. 65 . 2

IrY in Nartime, (pamphlet published by the National Youth sdminlstration, ligahington, D. C., about January, 1943) p. 8.
} 


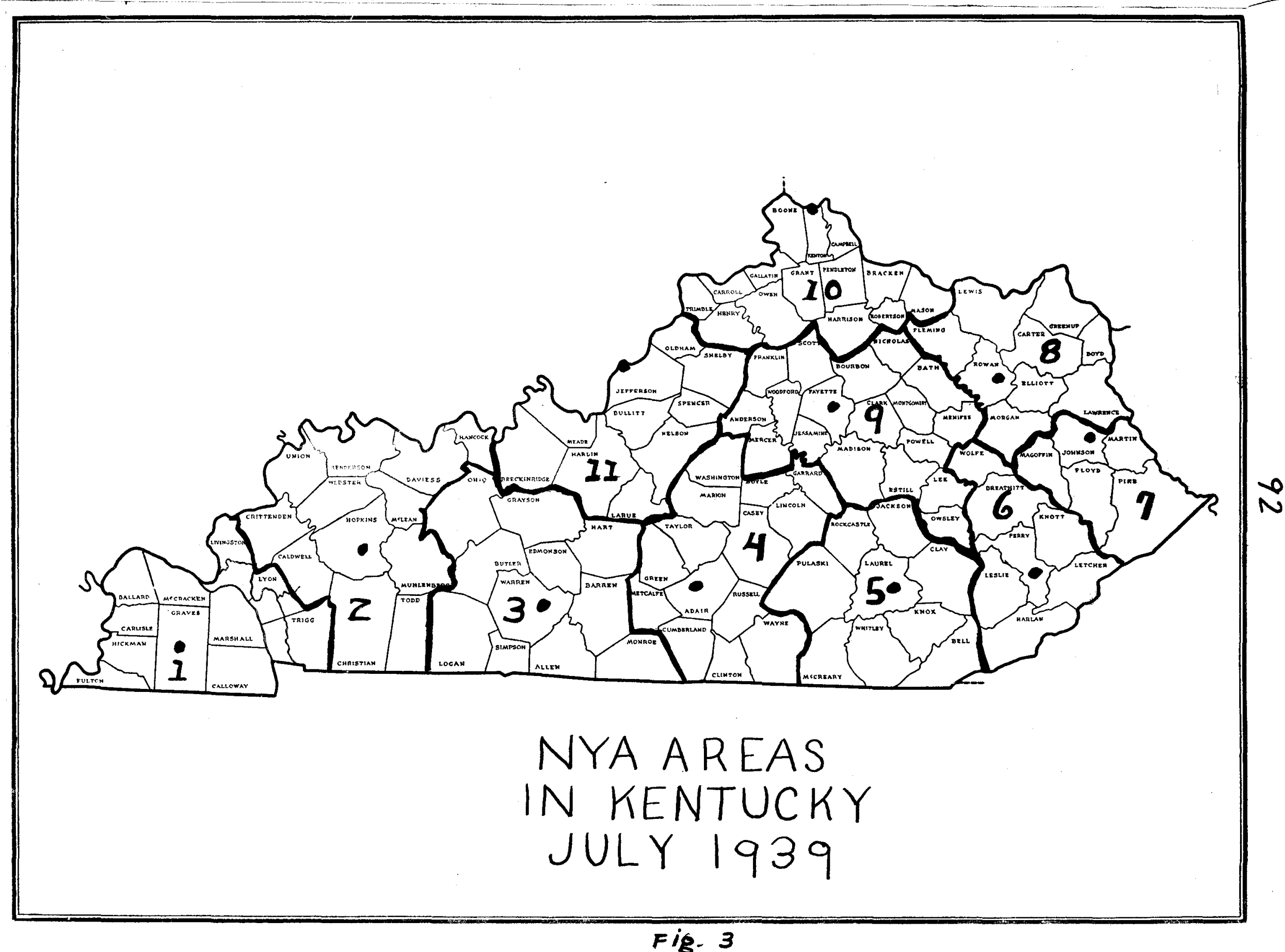


This divion of administrative authority lastod until the entire Iational Youth Laministration was abolishod by aot of Congress in July, 1943.

\section{PROGRUY DEVELOPMENTS}

Student Mid.-DIM student uid in Kentuoky oontinued through 1940 and 1941 in a pattern similar to that in 1939. In December, 1941, howeror, the Kentuoky State Offioe reoelved word that for the last half of fiseal jear 1942 the Iational Youth daministration would operate the sohool work program at 50 per oent of the planned employment. College and Graduate lid wore affoeted in the same way, and the amount spent for Kontucky student $11 d$ dropped from $\$ 884,999$ In 1941 to $\$ 161,506$ in 1948, and down to $\$ 74,910$ in 1948. Tables 6 and 7 show the corresponding drop in the number of students assisted and the amounts paid the young people during the months of Ootober and March from Ootober, 1939 to Maroh, 1943.

At a conference in Tashington in Lugust, 1940 prinalpals of sooondary sohools and representatires of state dopartments of eduoation mot with representatives of the United States Offioe of Bdueation and the National Youth

\footnotetext{
$\Gamma$

Supre, p. 65-70.

See Appondix B for expenditures by 11 soal jears Irom 1936 to 1943.
} 
Table 6

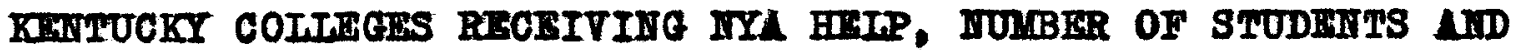
ITET PAYMETTS RECEIVRD OI STUDHTT AID PROGRUY FOR THE YOITH OF OCTOBTR, 1939, THE MOITHS OF MAROH AIID OCTOBER 1940 THROUGH 1942, AID THE MOMTH OF MARCH, 1943

\begin{tabular}{|c|c|c|c|}
\hline $\begin{array}{l}\text { Mouth } \\
\text { Ootober } 1939 \\
\text { Waroh } 1940 \\
\text { Ootober } 1940 \\
\text { Waroh } 1941 \\
\text { Ootobor } 1941 \\
\text { Waroh } 1942 \\
\text { Ootober } 1942 \\
\text { Waroh } 1943\end{array}$ & $\begin{array}{c}\text { Colleges } \\
\text { Partiolpating } \\
31 \\
31 \\
31 \\
31 \\
38 \\
38 \\
38 \\
89\end{array}$ & $\begin{array}{c}\text { Lamber of } \\
\text { Studonte } \\
1806 \\
1851 \\
1826 \\
1702 \\
1431 \\
1078 \\
494 \\
648\end{array}$ & $\begin{array}{c}\text { Iet payments } \\
\$ 22,360 \\
88,811 \\
19,663 \\
20,891 \\
16,54 \\
13,188 \\
6,696 \\
8,860\end{array}$ \\
\hline
\end{tabular}

\section{Table 7}

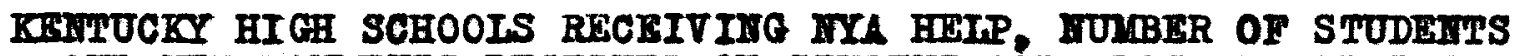

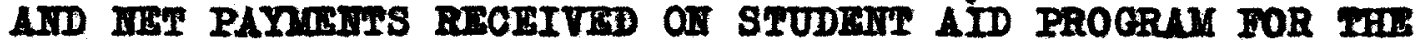
YOITH OF OOTOBLR, 1939, THE YONTHS OF MAROH $\triangle D$ OCTOBIFR 1940 THROUGH 1942, LID THE YOMTH OF MARCH, 1943

1

\begin{tabular}{|c|c|c|c|}
\hline $\begin{array}{l}\text { Honth } \\
\text { Ootober } 1939 \\
\text { laroh } 1940 \\
\text { Ootobor } 1940 \\
\text { Maroh } 1941 \\
\text { Oot ober } 1941 \\
\text { Maroh } 1948 \\
\text { Ootobor } 1948 \\
\text { Yaroh } 1948\end{array}$ & $\begin{array}{c}\text { H1gh Sohools } \\
\text { Partielpating } \\
650 \\
769 \\
602 \\
761 \\
566 \\
710 \\
394 \\
448\end{array}$ & $\begin{array}{c}\text { Tumber of } \\
\text { Student } \\
6201 \\
8077 \\
6198 \\
8098 \\
5099 \\
4011 \\
1866 \\
2198\end{array}$ & 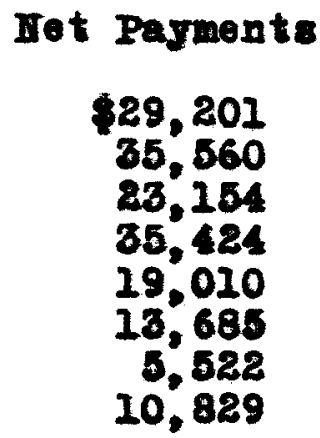 \\
\hline
\end{tabular}

Souree: H. Terry (compiled from uonthly Reporta to mashington by Ur. Terry, uggust, 1948) recelred by mall lugust 23, 1943 from 2040 Z. 96th St., Cloreland, Ohio, p. $2-3$. 
Ldminiatration to disouss moans of raising atandards on FIU stadent work projecte. It was tho foeling of this group that not only should the producte of atudent work be aseful, but there should be elose integration of work with students' interests, aptitudes, and potential oooupations. The derelopment of good work habits and attitudes should grow out of the experience as well. High quality supervision of student work and exchange of information oonoerning desirable types of projecte were regarded a eseential to the operation of onceesarul projeots. It was agreed that atate oommittecs oomposed of leading educators be organized to assume responsibility for giving assistance and adriaory counsel to sohool exeoutives in 1mproving the work projects for students employed under the Mational Youth Ldministration in 1 secondary sehoola. Suoh a committee was appointed in Kentuoky and was called the Sohool Work Couno1l. This group serred without compensation and adrised both sohool execatives and the state Fri in the sotting up and operating of Bohool work projecta.

18 the defonse and finally the war period eame IrA high sohool and oollege students were giren employment on

\footnotetext{
Youth on the Student Nork Program, (prepared by the Diriaion of Hinaree and statiatios, IrY, Washington, $D .0 .$, 19401 P. 64. 8

Ioretta K. Saljors to Dr. Irthur H. Robertson, Regional Direotor of Student work, IM, Columbus, Oh1o (ietter mitten, unguet 20, 1942) p. 1 .
} 
projects contributing alroatly to the war effort. A national enrrey of 200,000 IrA oollege jobe showed that orer 54 per cent were in flelda that had been deolared vital to the war effort, or in fielas in which aotual or imminent shortages of teohnical personnel existed.

Mort Projecte.-When ITU became separate Irom the Work Projeota Administration in 1939, the adninistrators of the jouth program folt that in their more indepondent atate It would be poseible to experiment even more ereely than before. Inoreased mphasis on training and the setting up of resident centers, therefore, tended to make projects larger, and hence they wore able to provide knowledge of a number of 8k111., enpecially those used in industry. In Ootober, 1940 the IrL was given apeoial funds to provide omploymont for needy joung people, betweon the ages of 17 and 24 , in resident and workahop projeots which supplied work experience proparatory to employment in defense oocupations.

Under the defense program only projects whioh furulshed work experienee preparatory to employmont in defonse ocoupations were eligible for the federal funds. This meant that the following types of omployment oould receive

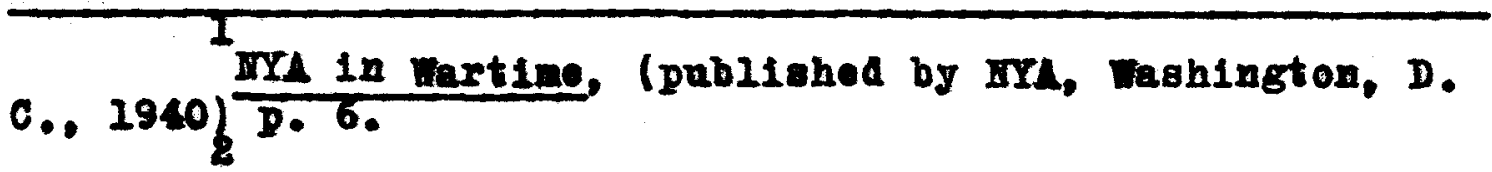

Smith G. Rose, Lohleremonts During War Poriod, (typewritten for Hational Youth idministration, September, 1943) D. 7. 
assiatanoe from Defense Program funds: ariation services, electrical, forge, foundry, machine, radio, shoot motal, welding, pattern-making and joining, and heavy duty industrial sewing shops. To make the most adrantageous use of NYl machinery and equipment and to provide skilled workers for defonse industrios as rapidy as possible, such shops were set up to operate as nearly as possible 24 hours a day ineluding three or more work shifts. To arold complieatlons defense projects were phyeleally separated from "Regular Program" projeots. Minimum hours of soheduled IrI work were inoreased to 80 per month. In addition youth employed on IIL defense projeots were expeeted to take rolated training courses offered by the sohool authoritios, arranged in ouch fashion that the oombined IYL and sohool programs cooupled 160 hours a month. Speoial care was taken not to omplog 16 jear old youtha as under the defonse appropriat10n, employmont was limited to youth botween the ages of 17 and 24. The Honse of Representatires Lppropriations Committee recomended that no jouth bo mployed by iry for more than 12 months, and it became the polloy to isave termination notioes to young persons who had been engaged on Ira projeots for twolve or more consecutire months. This poliey was not interpreted to require terminations in the midale of pay roll periods or in suoh a manner as would interfere seriously with the operating efficieney of a projeat. The Appropriations Committeo did not report favorably 
upon the rra request for authority to furnish oertain necossary medical cervioes to non-resident youth during the course of their omplogment with IrI, although the IrA was anthorized to provide emergenoy hospitalization and modioal oare in cases of oritioal 1liness or injury on the part of 1 resident emplojees.

As of Maroh 31, 1941 there wore 9,427 Kentuoky jouths ongaged in the following occupations: construetion, -lerieal, sheotmetal, relaing, auto-mechanics, machine shop, - lootrioal unit, radio construction and repair, woodworking shop, drafting and blue-printing, sowing, woaring, making of conorete blook, quarrying stone, sign produetion, making tont bases and camp toola, making of oinder blooks, saw mill work, and making of farm implements and equipment. The majority of the young men were employed on construetion and wood morking projeots, and the women were largels engaged in the sewing and olerioal ocoupations. In addition to this number 1,110 jouth, almost oqually difided into men and women wore emplojed on resident projeots in Kentuokg making a total of 10,637 aotive in all phases of the work program. At the same time that the reduetion by 50 per eont

\footnotetext{
1

IrA Letivities looording to Congregsional lotion,

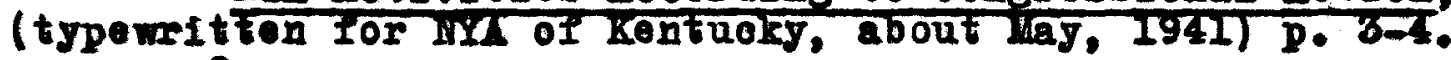
2 Report of Number of Youth Working on Varlous Types

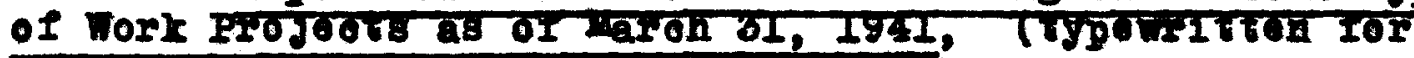
ina of Kontroky, about lay, 1941) p. 1.
} 
cano to the student work program in Kontuoky a similar roduetion oame to operationg under the out-of-8ohool work pro8xam. Tablo 8 shows comparative numbers of jouth and youth earaings for the month of ootober for the Jears 1939 to 1948 and for the month of June. 1943.

\section{Table 8}

ITULBER OF YOUTH IMPLOYED AND THEIR FARNIIGS ON IIY OUT-OT-SCHOOL PROGRM III KCHUTUCKY FOR THE MOTII OOTOBER, 1939 THROUCH 1942 IND THE YOUTH OF JUNR, 1943

\section{1}

\begin{tabular}{|c|c|c|}
\hline Yonth & $\begin{array}{l}\text { Inmber of Youth Limplojed } \\
\text { on Out-of-sohool Program }\end{array}$ & Rarnings \\
\hline $\begin{array}{l}\text { Ootober } 1939 \\
\text { Ootober } 1940 \\
\text { Ootober } 1941 \\
\text { Ootober } 1948 \\
\text { June } 1948\end{array}$ & $\begin{array}{l}5791 \\
3868 \\
8394 \\
8835 \\
5805\end{array}$ & $\begin{array}{r}\$ 82,377 \\
60,977 \\
135,816 \\
27,261 \\
86,519\end{array}$ \\
\hline
\end{tabular}

Because the National Youth Idministration Appropriation let for the fleeal year 1943 provided funds only for the operation of projects whioh were speolfioally approved by the Chalrman of the Nar Kanpower Commission as projects needed in the proaecution of the war and beoause the lot arastioally roduced the funds appropriated, all projects ander the "Regular Program" vere disoontinued by Julyl, 1942.

1

Souree: Id H. Terry loomplled Irom Monthly Reports to Waehington by Hr. Terry, Augugt, 1943, reooited by mail August 23, 1943 from Cleveland, Ohiol p. 1 . 
All area offices were closed at this time though some of the physical equipment was used for the war produotion training projects, the only phase of the rra out-of-sohool program continued after July 1, 1942.

During the last two years of its existenoe Wra in Kentuoky fabrioated numerous artioles for use by the United States Armed Servioes. Among these were radio mount1nga, water tanks, fleld kitohens, officer map boards, tablet arm ohairs, straight baok ohairs, typowriter desks, and thousands of atrapholders, straps of various sizes, and model minfature vehicles inoluding half-traoks, truoks, peops, command and reconnalssance truoks, tanks, trallers, anti-tanis suns, eto.

Although WY could not supply medical treatment to youths working on non-resident work projeots IrA in Kentuoky required every youth to have a physical examination in order to be employed in an IrIA Far Production and Training Shop. This enterprise sought to eliminate the possibility of training any who could not bo absorbed in war produotion and was made possible by the cooperation of looal physietans and publio health offloers. Young

Letter Ho. Y-254, Subject: Instruetions for Discontinuing Area Offices and All Projoots in Program Class 700 (Regular Program), June 18, 1942, p. 1, 7. 2

Artioles Fabrioated for urmy in NYA for Kentuoky Shops from Jaly 1, 1941 to June 30, 1942 (attaohment to letter from Kichard Iightfoot, Chlef of Production Seotion to Itason Offioer, Army Ira Lotivities, Fifth Corps Area,) p. $1-4$. 
peoplo examinea in this fashion were told of their defeots and were enoouraged to have them corrected either by their private physioians or looal public health offloials.

A system of interstate exchange of skilled defense workers was inaugurated by the WYA in cooperation with the unlted states Employment Service. Youth were required to have worked on the Kentueky IrA program for a minimum of six weeks and 160 hours before they were eligible for transfer to another state, except in cases of youth who were transferred to another training project under the agreement to stay three months, if necessary, for speolf10 training. All young people desiring to transfer were required to sign and have parent or guardian sign a statement of understanding and agreement for interstate transfer. When a joung person desired to be transferred to another state for employment and his foreman recommended that he be sent, a complete record of the young person's performance was sent to the atate Youth Personnel officor. Through the USES industries requested. skilled artisans and Kentuoky youth were transported to areas of acute labor shortage. Onoe in another state youth were immediately sent to a nearby IYA projeot whioh assisted the youth in finding employment and getting a residence established. Kentuoky

Press Release for Thursday, April 23, 1942, by the Irational Youth Administration for Kentuoky, $p .1$. 
sent many trained young people to Conneotlout, raryland, Hew Jerseg, Virginia, and Oh10. Travel expense was borne by the IIL.

The resident oenter program continued to the end of the administration of the Youth Program in Kentuoky under much the same organizational set-up as in 1938. In later gears transportation money was provided for youths to get to residence centers. For a short time a full program of medioal oare inoluding operative and dental treatment was provided, but in June, 1942, only emergency servioe was available for resident workers. In the last few years training was provided resident employees by the Vocational Fducation Program in Kentueky.

The provision that all training or oducational programs for youth employed under the IIA out-of-school work program should be under the control and supervision of the state boards for vocational education meant that administrative, supervisory, or youth employees would not be pald by Iru for time spent in teaching or receiving training in

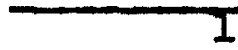

Saljers, General Letter 209, Supplement No. I, February 25, 1942, Subjeot: Ldditions and Revisions Made to the Washington Handbook of Youth Personnel Prooedures Revised Seotions, p. 2-3. 2

Supra, p. 80-82.

Letter Io. Y-166, Supplement IJo. 2, Nov. 19, 1940 to 11 State Youth Administrators, Subject: Relationship Between IYL and School Authorities with Respect to Work Lotivitios and Related Training. 
oltizenship, mathematics, blue-print reading, welding, or ang other educational subjeot. The provision of necessary direotion in the performanco of productive work, as an integral phase of accomplishing that work was not prohibited, however. Home-making projeots, household workers' training projeots, shop projects, or any other projects whloh could not be operated on a productive basis could not be proseouted by the Hational Youth administration for their training value. All projects were to have as their central purpose the production of facilities, goods or services which were socially useful. State Youth Ldministrators were to inform vocational eduoational authorities in the various states as to the kind and amount of related training that appeared to be needed by gouth on FYh. Attendanoe at training olasses, however, was not made a condition of partioipation in the 1 ITA work program.

Because of the difference in the philosophy of the VII and the Vocational Eduoation Boards in regard to eduoation, the usefulness of the National Youth Administration, and other matters, cooperation between the agenoies was not the best. On occasion the VI directors felt that III did not want to relinquish training facilities or wanted to take back such education projects as VE had taken orer. 2

$2^{I b 1 a .}$

Ietter from R. H. Foods, State Direotor, Vocational Training for War Production Norkers, to Wrs. R. K. Saljers, July 25,1942 . 
Sereral times the Kentucky State Department of Eduoation and the Kentucky Fational routh Laministration issued jointly statements of relationships of the two agencies and tried to blend their efforts for the assistanoe of Kentuoky youth, but with a few exoeptions relationships between the Eduoation and ris Works Projects programs were not completely satisfaotory.

$$
\text { Junior Placement Serviees.--Prior to July, } 1940
$$

the Iational Youth Administration oooperated with the state employment services in operating Junior placement offices as fow state employment services had Junior Plaoement facilities. It was the polloy of NIA from the begining to assist financially only until state employment offloes were able to take orer this phase of thoir work. At the request of Congress Mra disoontinued this function of the Division of Guidance and Placement in the state organizations 28 of July, 1940 .

The Tumber Served.--Between January, 1936 and July 3, 1943 approximately 145,210 individuals, aged 16 to 25 were trained by the IrA in Kentuoky on the regular out-of-sohool work program. The War Production Training Program served 21,600 youths in the year from July, 1942 to July, 1943. Altogether 166,810 Kentucky young people benefited from the

\footnotetext{
1

Memorandum to All State Youth Adminiatrators from Aubrey Willams, Fational Youth Administrator, Ootober 20, 1941, Subjeot: Lttach Information Concerning Alleged IYA Irregularities.
} 
work programs.

Approximately 32,900 high sohool students and 16,900 college and graduate students were reoiplents of Sohool Aid during the period July, 1935 to Jane 30, 1943. Emplogees of the out-of-sohool work programs and the School Aid together make a grand total of 216,610 Kentuokians who were served by the Mational Youth Administration. This achievement was made possible by the expenditure of about $\$ 29,972,405$ within the 3 state.

\section{A WAR CASUAITY}

Opposition to the National Youth Administration did not have strong adrooates in Kentuoks. The leading newspaper in the state, the Ioufsrille Courler-Journal, supported the program oonsistently, and when the fate of III hung in the balanoe after the House of Representatives had roted to ilquidate the youth program, the courier carried vigorous editorial opinion to the effeot that IrA was doing a good job training war workers and should not be allowed to die because of the insistent lobbying of the offioe of education

Fd H. Terry, lestimates drawn from Monthly Reports to Washington, Sept., 1935 to June, 1943 of Kentuoky and Region V IMA), reoelved by mail, sugust $23,1943$.

2 IbId.

Federal Funds Expended on IYA in Ty., Fisoal Years 1936-1943, I.I. Valentine, Direotor of Finanoe and Statistios, ITY, Washingtion, D. C., reoeired by mail, ootober Il, 1943 . 
and many other state educational administrations.

The press of the nation, however, was divided on

the issue. In years prior to the final argument as to

whether MYA should be continued there had been mach debate

in the Congress and in the nation's news papers as to the

merlts of the program. The Salem Oregon Journal of March 6,

1942 stated:

National Youth Administration direotors throughout the countiry are finaliy awakenIng to a fact of which the general publio has long sinoe beon oognizant, namely that they are wasting publio money on aetivities, whioh if they were justified by the work they made for unomployed girls and boys, oertainly have outlived that justification in these oritical times of labor soaroity and national need." 2

4 contrasting view appeared in the Hew York

C1ty PM on Varoh 10, 1942 as follows:

Morst news from Washington--as will be surprise to the readers of PL- is on the home Iront, Rooserelt's personal opponents are indeed having a fleld day in Congress. Leaderless, because the boss is busy with his produotion ohiefs and his generals, the Hew Deal's forces are as scattered as a Balkan army hit by an Hitlerian blitz. And indoed it is an Hitlerian blitz that has hit the valuable social agonolos so painfully built during the last elght jears. It is an attaok upon $130,000,000$ people by a small group of unsorupulous men who believe in foroo.

"This Is Iot the Time to Abolish MYA", The
Courier Journal, Iouisville, Ky., June $26,1943, \frac{560}{1, \mathrm{p} .6 .}$

Weokly Summary of Editorial Comment on the rYA, 3131, EC 90, National Youth Ldministration, March 14, 194. 
"The sad part is that the defenders of the Hew Deal are not only right--agenoles like the Farm Seourity Administration and the National Youth Administration etc., are vitaliy important to us in our total mobilination--but they also have the overwhelming majority of the people behind them--and yet they are being pushed around for want of the disoiplined organization and the compact unity of their enemies. $n 1$

The agenoies lobbying most earnestly against the

Youth Administration were the education assoolations. In a threo-page letter dated uay 27,1943 sent apparently to the seoretaries of all State Rducation Assoolations, Mr. Fillard Givens, the Exeoutive Seoretary of the rational Education Assoolation urged an Immediate oampaign of pressure upon Congress to abolish the Mra. Mr. Givens oharged the WIX with ndupliegting the work being done better by the public sohools and at a cost that is unreasonable." He substantiated these charges by giving h1s own interpretations of the FIA Budget Istimates for 1944 and the Report of the Joint Conmittee on Reduction of ronessential Federal Bxpenditures; he further argued that Wl was usurping a task which rightfully belonged to the office of Edueation. When the Iational Youth Administration interpreted the same I1gures and replied to Mr. Givens' arguments the etory appeared in quite a different light, but it is doubtful

Moekly Summary of Baitorial Comment on the Irational Touth Administration, 3131, EC 90, Hational Youth Administration, Haroh 14, 1942. 2

Statement Regarding Willard E. Givens: Ietter of May 27, Wational Youth Ldminlstration, (rooelved by ma11 Irom Iir. Ed. H. Terry, Cleveland, Oh10, August, 1943), p. 1-11. 
if the eduoators geve the HYl interpretations much oredence. There were oritioisms made that the MIL operated Junior Bmployment offioes contrary to expressed wishes of Congress, obstruoted army reoruiting, and reduoed ago limits in order to obtain additional youth labor. NYA repliea that finanoial assistanoe given by the rra to the junior placoment activities of the state emplogment servioes wes discontinued completely in July, 1940, in aocordanoe with the wishes of Congress. On January 18, 1940, nearly elght months before the passage of the selootive Service det, the National Youth Administrator sent a memorandum to all states speolfioally direoting them to cooperate in the army reorulting drive, including furnishing lists of youth employees to army reorulting authorities and arranging meetings at whioh army representatives explained to IIA workers the opportunities offered by the army. As a result of this memorandum part of the organized youth movement protested vigorousiy against the FYd polioy. Mr. Wlilams replied that he folt overy oitizen had a right to information with respect to enlistment in 1ts armed forees. Critiolsm that rra reduoed age limits was likely due to misunderstanding of administrative polioy. MY did not employ youth under 18 who

\footnotetext{
Iocording to Dr. W. P. King, Exeoutive Seoretary of
} the Kentuoky Edueation lssooiation the views of Kentuoky education in regard to MIL followed those expressed by the MA, but relationships between the KA and the Kentuoky Administration of IIA remained cordial due largely to the fact that IYl state direotor Hobert Salyers, a former cha employee, worked so harmoniously with kentuoky sohools. 
might otherwise have remained in school, but ald supply work to unemployed out-of-sohool youths who were 16 and 17 . Other objections to IIA revealed fears of federal control of education, that IIA was duplicating other training programs and that IIA youth had to be retrained onoe they were employed by industry. Cries of a "mushroom" growth of federal bureaus since Pearl Harbor addod their force to werken support of Fra. These fears plus the insistence on abolishing all "nonessential" tax supported programs during the war by rote-consclous senators and representatives were in part responsible for the Congressional vote whioh Ilquidated the program in July, 1943.

Aubrey Williams, Yemorandum to all state youth administrators, 0otober 20, 1941, Subjeot: Attaohed Information Conoerning Alleged Fra Irregularities. 
CHAP TER V

CONCIUSIOHS 


\section{CHAPTER V}

\section{CONCIUSIONS}

FIA in Kentuoky and the Youth Problem

The story of the Mational Youth Administration in

Kentuoky would not be complete without an inquiry into

the extent to which the youth program in the state succeeded, in meeting the multi-fold needs of young people which in aggregate oomposed the 1935 Youth Problem. It will be reoallod that the IIA sought to "do something for the nation's unemployed youth" beoause the country could not afford to lose the skill and energy of her young men and 2

women. Obriousiy something was done, but just what did the ooming of Irl mean to Kentuoky joung people?

One of the primary IIA ways of assisting the unemployed youths whose familiea were on relief was by giving financial help through the schools. This method kept the number seoking jobs from swelling so rapidiy beoause more

\footnotetext{
Supra, p. 7-15.

2

Franklin D. Roosevelt, statement at oreation of the Irational Youth daministration, June 26, 1935 (quoted in First Annual Report of Iouisvilie's Junior Placement and Counseling Division of the Kentucks State Emplojment Service, September, 1937, p. 2.).
} 
youth could remain in sohool if they had a small inoome. Then, too, some who had stopped sohool for finanoial reasons were able to return when they knew their further education would not be a oomplete monetary liability to thelr families. Undoubtedig there was greater equality of educational opportunity for Kentuoky young men and women because of the coming of IIM, and the Youth Program used 1ts resouroes generousiy to moet this important need of youth. Even with the help of Mrd there were still many people in noed of moneg to IInish their educations because the program could not possibly have served all noedy youth with its limited funds. In spite of the elaborate publioity campalgns undertaken by IrI there is reason to believe that some youth did not arail themselves of the opportunity because of laok of knowledge or understanding of the purpose of the program. Beoause of the newnoss of the undertaking, the speed with which it was set in motion, and the fact that looal administration of IrI was an additional burden to busy school and college exeoutives and faoulty, there were lnefficleney and isolated lastances of young persons' reoelving help who oould easily have continued in sohool without 1t. Had the FI state offloe been able to afford field workers for the student ald program the job might have been done more effeotively. It was the desire of both the sohools and IIA to hold administrative costs to a minimam, but it would seem that a larger portion of the money arailable oould have been well spent for more eareful 
supervision all down the 11ne. Should there be another national program for youth (and it is possible that such an organization will be needed in the United States after Forld War II), it will not be necessary to train all personnel as was the case with the depression-born IrA. There will be a residue of individuals who were weaned on the former program and who will be able to carry on and improve a second youth program.

Student lid funotioned in as many different ways as there were Kentucky schools to reooive it, and the results were as heterogeneous. Espealally the colleges, with a lew exoeptions, had good programs, but the consensus seems to have been that running III effectively in a college consumed as much as one-half a person's time, and that to have the most sqocessful results allowanoe would have to be made for such a person in the college budget. Another youth program might well consider the advisability of requiring or providing such assistanoe to the oolleges to administer the work 1002lly. It is faif to say, however, after considering all phases of Student $11 d$ in Kentucky, that III made a stand for greater equality of educational opportunity in the state and made vigorous, oonerete movements toward the achlerement of that end. To the oredit of the program it can be sald that raoe, sex, religious conviotions, and political affiliation, did not bar youths from reoeiving help. 
ITA struok with all its foroes at the problem of unemployment for youth. In four ways it taokled that issue. First, part time work was provided needy, unemplojed youth. Second, tralning was given the young pooplo to equip them for a job in private industry whenever there were openings. Then, contact was kept with employers through the use of the faollities of employment offioes and directly with individuals, and last, guldanoe and rooational oounseling were provided the jouth in indiridual consultations, group disoussions, and by the widespread distribution of 11terature designed to help youth find a plaos in the industrial economy. It seems that we have presented ovidence that each of the four attacks was partially sucoessful, and espeoially did the War Produotion Training Program prepare young persons for a real plaee in the existing eoonomy. In this area also the laok of adequate supervision marred the effort, but supervisors could well have used many skilis beside the one they hoped to impart to the youth, and MrA wages for this olassifleation of employees were often unable to buy the type of personnel who would have been able to hande construetively all the demands on their time and ingenuity. Here, too, new youth program could learn from the old. Supervisors should be carefully ooached along many Iines if their performanoes are in any way to measure up to the neods. III in Kentuoky olearly reoognized these neods and tried by means of supervisors' institutes, olose supervision of 
supervisors, and other means to provide the personnel which was so badly needed.

It is diffioult if not impossible to measure the suocess of Hra's war on unemplogment at this time of almost full employment. No complete follow-up records on young people served by WM in Kentuoky esixt, though an effort was made to keep such information as could be secured. It is reasonable to assume, however, that a large proportion of III "alumn1" serving in the armed forces and in war industries are using to some extent the skills and work habits given them by Irra. Through its Junior Employment Servioe and other contaots with employers, IYA placed hundreds of young people in jobs and provided 166,810 Kentucky youth w1th part-time jobs from 1936 to 1943 . WYa did not solve the problem of unemployment for youth, but it gave material help along that line when the problem was acute and continued to help young poople improve their positions up to the time of the liquidation of the program.

$A$ third need of gouth in addition to a fair ohanoe for education and jobs was a feoling of economio soourity. Ira provided oomplete eoonomio seourity for very few, but the program was a step in that direotion. IrY employees recolved money that was theirs, and having power over even their small stipends would soem to have addod to the selfoonfidenoe and independenoe of the young people at a time in their lives when desires to be responsible and behave 
in an adult manner should be increasingly realized. Lgain, youth in 1935 noeded release from blind alley jobs, from disoouragingly low wages, too long hours, and too early and too heavy family responsibility. Wra - helped here by arrawing off from the labor market the least adequately prepared workers, making it possible for other youth to move up slightly in their soales of living as oompetition for low-paying jobs deoreased. IYA in teaching valuable skills and in giving experienee even in unskilled work helped young people erase part of the job-diseouraging epithets of "unskilled" and "unexperienoed." In later years under the defense and war programs Irrs trained youth were able to step into $40 \phi, 60 \phi$, and even $80 \phi$ an hour jobs, a far ory from the lawn-mowing and errand-boy jobs of a few years ago. Nlthough an effort was made by IrI to follow up its workers, it was not possible to measure the number of youth who were given such employment. Of oourse, the full oreait for plaoing youth in such remunerative positions cannot be taken by IrIa, bet the Youth Program saw the openings and trained its emplojees in order that they might take advantage of the opportunities. Far industries, too, were saved the expense and time of training raw recruits from a drying up labor markot.

It would be deffoult to prove that IrYA moved a large number of youth from blind alley jobs to positions with a -lear and bright future. Certainly it is hopea that many of 
the war oooupations are temporary, but with the reconversion to peace time pursuits of the major industries, it is reasonable to suppose that many of the same skills will be noeded in peace as were employed in war, if we are able to keop employment anywhere near the war-time peak. Experione in war plants will surely be helpful to young people seoking employment when the peace has come. Regardless of what shape the economio ploture assumes in the near future, ITA training has given many persons greater job seourity for the days ahead. In some instanoes skills learned on IrA projects during the early years of the program were of little if any marketable value in the communities where the youths lived. A new program whether federally or loeally sponsored should oonsider the possibilities of future use of tralning before offering it to persons who have few if any skills.

Emphasis throughout all phases of NYA was placed on vocational guldance and counseling. Beyond a doubt this service was the first from an objective point of view that many of the young people had ever recelved. Probably many did not have faclitiles or resouroes for using the servioe, but if most of the young people reached were given better insight into the employment problem faoing them and took the courage to look about them and try different vocational experienoes in an effort to learn where they would 11t, then Ira did not fail in its attempt to counsel youth on the question of how best to prepare for and secure adequate 
employment. Wide use made this part of the Youth Program Important and avallable to hundreds of youth who needed it. Again we cannot measure exactly the effect of this enterprise, but its oduoational value was high, and Kentuoky schools reoeived an impetus to explore further the guidanoe field beoause of the example set by Tra.

Vocational training proved to be a mejor service of the Youth Administration. The quality and the usefulness of this aspect of the program improved steadily until the maximum coordination of training and placoment oocurred under the War Produotion Training Program. In the early years job opportunity did not necessarily follow training because employment opportunities were limited and beoause some of the skills taught did not have immediate use for the boys and girls. This latter situation was reoognized by IrI in Kentuoky, but it was not always possible to adjust work projeots to teach vooational skills that were in demand by the labor market espeolaliy when employment was at suoh a low ebb. Good work habits were bred in the youths and conditions in private industry were simulated in WYA shops when practical. It can be sald that by bridging the gap between sohooling and f1rst jobs FrA contributed materially to the potential job suocess of the majority of the young people who worked on the Youth Program.

IIIA battled the leisure time problem. When they aooepted IrS employment, the unemployed fillod one-half their 
101sure. In resident oenters but also in the non-resident projeots mech attention was given reoreation for the joung men and women. Group games were taught, hobbies eneouraged, and cultural adrantages offered. Reereation projeots were partioularly weloome not only to the projeet youth themselves but to all the residents of the benefiting communities. Disenssion groups, pamphlets, and physioal examinations and treatment gave many young people a better chanoe for good health. Questions of soolal hygiene and family health were presented espeoially to the girls, Alhough far from prov1ding complete health edueation for partiolpants in the program, IYA was aware of needs along this line and used avallable resouroes to supply the needs.

The olvio responsibility of all oftizens in a democraey was streseed to IrI jouth, but it is probable that having jobs and a stake in the ooonomio future of the country will be more meaningful to the joung people than any of the dsougsions they heard. Here again IrA rosouroes were limited, time was short, and the hoterogeneity of the jouth serred made courses of this type diffionlt to offer. It 18 signifloant that rul rocognized this neod, and It is our opinion that other youth serving ageneies either operating now or that will operate in the future would serre this oountry and our world by helping to derelop a fooling of responatbility in young people for the eareful exerolsing of 
their eitizenship in both.

IrY oame far from solving the problem of laok of unity of purpose and effort among the youth serving agencies. By contaoting and adrising with a large number of such organizations, however, ITA helped foous the Youth Problem In the minde of thinleing poople and gave muoh publiolty and some understanding of the issues involted. Those who seek to cerve youth have here a large fleld of endeavor.

We can but conclude, then, that while FYA did not anewer all questions for youth or provide the way out of the alley of two blind onds for every joung person ooming to the agenoy for help, the program was a stop in the right dirootion. Bxisting conditions were laced realistioally, and III aooopted young poople where they were and tried hard to faclilate their adjustment to twentioth oontury living and to help Kentuoky youth oome into a part of what should be their natural inheritance.

\section{INPLIOATIONS FOR THE FUTURE}

Wo have in this study attempted to define the Youth Problem and to deseribe the manner in whioh the liational Youth Ldminlatration oought to solve that problem in Kentucky. There romalns for us to draw together what we have learned from exporienoing IrS in this state and set it down as a 


\section{2}

poseible land mark for ruture soolal planners. Immediately apparent is the laot that the Youth Problem is not 1nherently different from nor soparate from the sooial problems faoing all our eltizens erorywhore. In tentuekg we eannot solve the Youth Problem unless and until we make real headway on the Race Problem, the Labor Problem, and the questions of rollef and unemployment, agriculture and farm tenanos, housing, edueation, interstate trade barriers, and duplioation of gorermmental units. And of major importanoe, wo oannot give jouth the fullest opportunity unt1l wo hare solred the problem of war. Youth, too, wast have a faith, a moral code, and a belief in the Fatherhood of cod and the brotherhood of man if anything approaching the abundant I1fe 18 to be achiered.

Ithough the National Youth Administration did a oreditable job under diffioult ofroumstances and was aboIlshed before its term of service was ended, it seoms elear to us that had industry, the sohools, the soolal agereles and oharohes, and the young people themseltes been operating at their best oapaolties rul would never have boen noeded during the turbolent 1930 's or into the warsore 1940's. In a highly effleiont soolal and politieal coonong moh a patoh-work agenoy as the IrI would hare no place. Fach of the needs of youth which FYA tried to meet could have boen and should have been serted by already existing soolal institutions. With the use of 1magination 
and courage the sohools oould make their programs attractive to most young people and could erolre ourrioule to if the conditions of living today instead of eatering to the requirements of the 1920 's or eren earlier days. Vocational guidanoe, health edueation, suggestions for the use of lelsure and facilities for reoreation, edueation to oivio responsibility, all eould be prorlded in an interesting fashion by the sohools if they would. Lohiering equality of educational opportunity for all raelal and inoome groups also requires courage and understanding on the part of the eduontors who could assist dicadrantaged persons in einding employment necessary to remining in sohool.

Industry could provide a real soolal service for jouth. Payling a living wage to all personnel will help parents afford education for their ohildren; working elosely with the sohools in arawing up currioula, in enoouraging employees to return to sohool when adranoement is hindered by laok of training, and in giving small jobs to jouthe working their way through sohool are legitimate funotions of induatry. Rooreation programs, health services, and rooational oounseling could be supplied by industry working in cooperation with employment services.

Soolal agenoles could holp with problems not touched by other groups, and the ohurohes should assist youth in working out their philosophies of living and in finding a falth to gro maning to life. 


\section{3}

But, we have not reached Utopia, and emergenoy programs will doubtless be required again in the future. From the experience of ma we have learned that youth respond to an out-of-the-classroom approach to edueation partloularly when they can see the reason bohind and the results of their learning. The teachers of our oountry might take note of the suocess of this method and revamp muoh of the academio program along lines that will be more attraotive and more practioal for their pupils than some of the unimaginative methods now in use. At the outset of IrI the United States Offios of Bdueation felt that it should administer the funds arallable for a Youth Program. Perhaps they had just eause for believing as they did, but until the edueational system prores it desires to and is ablo to reach the young people serred by IrA, it is quest1onable whother inoreased applioation of the olassio graded approach to loarning will be the answer to the lack of equality of educational opportunity and the dirootly rolated employment 18sue. The 1943 federal sohoolald plan whioh was sponsored by the Offioe of Bdueation, had it rooelred Congressional approval, would have gained some oquality among the states by proriding funds to supplement the echool budgets of the edueationally retarded southern states.

Controlled migration of labor under the IrI interstate transfer syatom was an innovation for young people 


\section{4}

that should be dereloped and utilized. Should a new youth program laok resident faollities a cooperative arrangement botween the United States Tmployment Servioe and looal Young Men's and Young Women's Christian ds8001ations or other agoney equipped to help youth adust to a new community, might assist in achlering the plaoing of labor where 1t oan be used to the bost adrantage for all concerned. In Ine with the theory that there should be jobs for all who are willing to work regardiess of their economis status, 1t would seem only fair that there should be part-tlme jobs arallable for all joung poople who want to supploment inoome while in sohool both during the sohool sessions and in the summer months. Fitting job opportunit1es to youth labor at the time it is avallable will be an exacting task for soolal planners.

It may neror again be possible to direot youth to Iine, Iree land somewhere in the west, but as long as there 18 work left to be done, young people should be trained and oncouraged to fulfill their ambitions, for youth is willing to work. IMA performed a servioo; there yet remains a job to be done. 
APPEIIDIX 
IYL ORGANIZATION II KETUCKY 1935 - 1936

State Ldrisory Commitiee:

4re. Sam Hatlaok, Louisville

Ben Hiles, Henderson

Yanoy Iltsholer, Ioulaville

J. D. Freeman, Iexington

George Braton, Ioulsville

James $\nabla$. Cammaek, Jr., Frankfort

H. I. Donotan, Riohmond

I. Will1s Cole, Iouisville

State IrA Direotor:

Frank D. Poterson

Aselstant Dirootora:

Robert K. Saljers, Lasiatant State Direotor

Ot1s C. Amis, Vooational Information and Community Lotirity

T. Lroh Bennett, IYY Work Projeots

M188 0 . Ilter, Projeot Operation

T. E. Bromn, Hogro Lotivities

Distriot and County Sot-up:

Distriot 1-26 Counties-Bd H. Terry, Supervisor Josge M. Hunt, Lse1stant Paduoah, $\mathrm{KJ}$.

Distriot 8-21 Count1es-B1rger Ó. Berg, Supervisor Campolleville, $\mathrm{KY}$.

Distriot 3-23 Counties-larix J. Bridges, Supervisor Corington, $\mathrm{KY}$.

Distriet 4-18 Counties-Herman B. Hubbard, Supervisor Iondon, $\mathrm{Ky}$.

Distr1 ot 5-17 Count1es-Frenoh 1. Magsard, Supervisor Paintsvilie, Ky.

Distriot 6-15 Count108-II0110 F. Dunaway, Supervisor Iouievilie, Ky.

Alen B. Cammark, Asaistant Supervisor at Large 
FRDERAT TUIDS EXPIITDED A/OII ITIA PROGRAUS III

\begin{tabular}{|c|c|c|}
\hline $\begin{array}{l}\text { Fiscal } \\
\text { Year }\end{array}$ & Total & $\begin{array}{l}\text { Out-of-Sohool } \\
\text { Work Program }\end{array}$ \\
\hline 1936 & $\$ 1,001,214$ & $\$ \quad 474,497$ \\
\hline 1987 & $2,243,861$ & $1,466,822$ \\
\hline 1938 & $1,492,144$ & $1,088,314$ \\
\hline 1939 & $1,822,510$ & $1,393,649$ \\
\hline 1940 & $2,123,273$ & $1,541,181$ \\
\hline 1941 & $3,084,261$ & $2,467,841$ \\
\hline 1942 Combined & $2,892,439$ & $2,473,461$ \\
\hline $\begin{array}{l}\text { Regular Program } \\
\text { Defense Program }\end{array}$ & $\begin{array}{l}1,483,114 \mathrm{~d} / \\
1,285,261 \mathrm{~g} /\end{array}$ & $\begin{array}{l}1,188,200 \\
1,285,261\end{array}$ \\
\hline 1943 & $1,655,919$ & $1,501,618$ \\
\hline GRUND TOTAT & $16,315,621$ & $12,402,383$ \\
\hline
\end{tabular}

4/ Data for Ifsoal years 1936 through 1940 are aotual expenditures derived from Treasury reports of voucher payments. Figures for 11soal years 1941 through 1943 are onoumbrances obtained Irom wil finanoe reports. B Fund expended for administration for fiseal years 1936 through 1939 were ineluded in amounts expended by the work Projocts Administration.
KEITYUCKY FOR FISCAL YTLRS 1936 THROUGH I943

\begin{tabular}{|c|c|c|c|c|}
\hline & student & \multicolumn{2}{|c|}{ ors program } & \multirow{2}{*}{$\begin{array}{l}\text { Toministration } \\
\text { and Printing } \\
\text { and Binding }\end{array}$} \\
\hline & Total & $\begin{array}{l}\text { Sohool } \\
\text { Mork Program }\end{array}$ & $\begin{array}{l}\text { College and } \\
\text { Graduate }\end{array}$ & \\
\hline & 526,717 & 324,458 & $\$ 324,458$ & B/ \\
\hline \multirow{9}{*}{$\$$} & 777,089 & 432,934 & 345,005 & B/ \\
\hline & 408,830 & 289,574 & 169,256 & B/ \\
\hline & 488,861 & 246,166 & 182,695 & B/ \\
\hline & 485,217 & 283,367 & 201,850 & $\$ 96,875$ \\
\hline & 488,958 & 284,999 & 197,959 & 133,462 \\
\hline & 294,914 & 261,506 & 138,408 & 124,064 \\
\hline & $\begin{array}{c}294,914 \\
200 x\end{array}$ & $\frac{161,506}{200 x}$ & $\begin{array}{c}133,408 \\
20 \times x\end{array}$ & $x_{200 x}^{\infty 00}$ \\
\hline & 154,301 & 74,910 & 79,891 & D/ \\
\hline & 558.837 & $2,047,014$ & $1,521,823$ & 354,101 \\
\hline
\end{tabular}

c/ Inoludes tunds ancumbered for administration and printing and binding for each program separately. D Iri Programs were administered on reglonal besis, Therefore, data for Kentuoky not arallable. 
BIBIIOGRPAX

• 


\section{BIBLIOGRAPHY}

\section{Boole}

Be11, Howard Y., Youth Te11 Their Story. Washington, D.C.: I imerlean counoli on baroation, 1938.

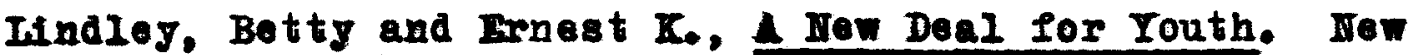
York: The Viling Press, 1968.

\section{Reports}

First Innual Report, Iouiarilie's Junior Pleoement and counseling Ditision of the Kentuoky State Imployment service. Iouigril1e, Ky.: September, 1937.

General Report. I Resume of the Kentuoky Youth Program. 10uisilie, Ky.: National Youth Ldministration for Kentuoky, Apri1, 1936.

Ionthly Reports to Nashington. Summires of aetivities of tio lational routh Iaministration for Kontuoky by monthe. Loulevil1e, KJ.: Soptember, 1935-June, 1939.

Iational Youth Aministration innual Report for the Year Laling dune 00,1940, propared by the Division of Finanee and Statistio8. Waghington, D.C.: 1940.

Report of the Bmergenor Flood Rellef Let1vities, January and rebruary, 196 of the lational youth raminis-

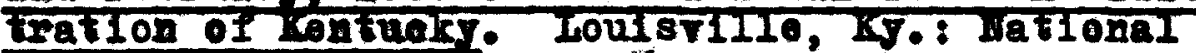
Touth raministration for tantuoky, Waroh, 1937.

Report of the Iational Youth Maministration for Kontuck. propared for the commitioe on ielior and unemployment in Kontuoky, Southera Conferenoe on Human Welfare, Dr. Margaret K. Strong, Chairman. Houls1110, Ky.: Iational Youth Ldminiatration for Kentueky, about Jaroh, 1940.

Repart of the Iumber of Youth Forking on Various Types of

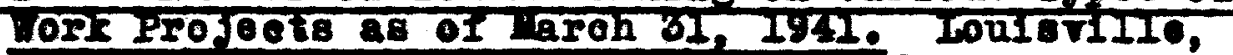
E.: Lational Youth Idministration for $\mathrm{KJ} \cdot$, Haroh, 1937 .

Salyers, Robert $K$, Report on the IYA Program, Submitted in Leoordanee Fith Riohard Brown's lomorandum Dated Oetober 9, 1937. Iout8r1110, Ky.: Ootober, 1937. 
Woekly Summary of Bditorial Comment on the IIA, 3131 EC 90. Lahington, D.C.: laroh T, 1942.

Fook1y Summary of Bditorial Comment on the IrI, 3131 EC 90. heshington, D.C.: laxen 14, 1942.

Williams, Lubrey, Report of the Fational Youth Laministra-

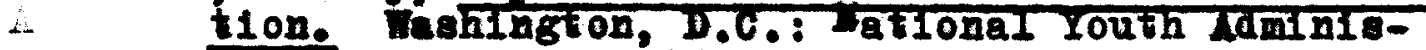
Tration, Hay 16, 1939.

Youth and the Future. The General Report of the Imerican routh commiseion. Waskington, D.C.: Imerioan Couneil on Edueation, 1942.

\section{Pamplets}

Amis, Ot1s C.. Basie Information on IYl morkers in Kentuoky.

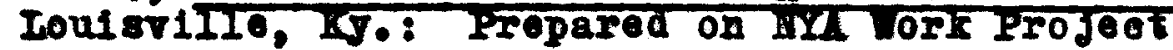
under supervision of the Dirision of Eduoational 11d, Hovember, 1936.

Gutdenee Lameal for the Use of MII Project Supervisors. 10udarille, 4V.: iational routh laminigtration for Kontuoky, Lugust, 1937.

Jaoobson, Pavl B. (od.), Youth and Work Opportunities. Reprinted from the Bulletin of the Hational As8oo1ation of Secondary-Sohool Prinelpals of the Hational Eduoation 4s800iation, April, 1940. Publishod by the Hational issociation of Secondary-Sohool Prinoipals, 1940, (aity not given).

Johnson, Palmer O; and Frrey, Oewald I., The Hational Youth Adin1stration, Staff' Study, Iruber Ib, Propared Ior tho IATisory Commitiec on Rdueation. Tashington, $D$. C.: United States corernment Printing Offioe, 2938.

III Let1ritien Looerding to Congressional setion. Iouistille, 4y : Iational Youth Laministration IOF Rontuoky, about lay, 1941.

FYA in Wartime. Washington, D.C.: Iational Youth Administration, about January, 1943.

Peters, Gaye $\mathrm{K}_{0}$ and Wright, Arkley, Mra Tork Projeot Program in Kentuoky, 1936-1937. LourstiII0, ky.: iationaI Youth Idministration Ior KJ., Dooember, 1937 . 
Ross, Smith C., cohierements During the War Period. Iondon,

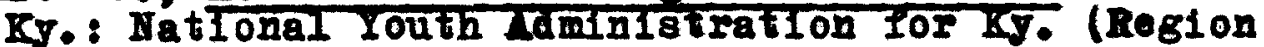
T), 1943.

Salyers, Robert K., Faots 1 bout III in Your State. Ioulsv1110, Ky.: Iational Youth Laministration in Ky.. Naroh, 1940.

Planning Your Student 4ld Fork Program. Iouisville, Ky.: lational routh Idministration in $\mathrm{KJ} .$, September, 1936.

Some Feota Lbout Touth and the Tru. Washingtion, D.C.: Iational Youth Idministration, Maroh, 1940.

Valontine, I.I., Rerion of lotivities 1935-1936. Iouisville, Ky.: lational Youth Iaministration for Ky., Fobruary, 1937.

Youth on the Student Fork Program, Washington, D.C.: DITIEion of Firavor and Statist108, National Youth Administration, 1940.

\section{Iowepapers}

The Courier-Journal, Section I, June 26, 1943. Ioulsville, KJ.: The Courier-Journal and Loulavillo Times Companj, June, 1943.

IrI Ohroniele, Vol. I., Ho. 1. Louisville, Ky.: Irational routh idministration for Ky., Maroh, 1937.

Press Release. Ioulsville, Ky.: Hational Youth Idministration for Ky., Tharsday, April 23, 1942.

\section{Ietters}

Artioles Fabrieated for Irmy in MYA for Ky. Shops from July 1. 1941 to June 30, 1942 (attachment to letter from Riohard Iightioot, Chiof of Produotion Seotion to Ilason Offioer, Irmy IYA Lotivities, Fifth Corps (rea.)

Letter NO. Y-166, Supplement Ho, 2, to All State Youth Adminlatrators, Subjeot: Rolationship Betwoen Bra and Sohool suthorities with Respeot to Work Lot1v1tie8, Iorember 19, 1940. 
Ietter I0. Y-254, Subjeot: Ingtruotions for Disoontinuing urea Offices and 11 Projeots in Program Class 700 (Regular Program), June 18, 1942.

Poterson, Frank D., to Riohard R. Brown, Assistant Bxecutive D1rootor, Hational Youth Ldminiatration, February 5, 1936.

Salyers, Loretta K. to Dr. Arthur H. Robertson, Reglonal Director of Student Work, MrA, Columbus, Ohio, August 20, 1942.

Salyers, Robert K., General Letter 209, Supplement Io. 1 Subjoot: Ldditions and Revision Made to the Washington Handbook of Youth Personnel Prooedures - Revised Seot1ons, Fobruary 25, 1942.

Terry Ed H., Division of Personnel, Region V., Clereland, Oh10, to athor, Ingust 23, 1943.

, to arthor, Angust 29, 1943.

Valentine, I.I., Direotor of Finance and Statistios, National Youth idmin18tration, to author, Ootober $7,1943$.

Statements

Poterson, Frank D., Radio Diseussion of Youth Problems and iry Lotivities in Kentuoky and Indiana, presonted over Station WAVE, Louisville, KJ., 6:30 P.M., Decomber 15, 1937 .

P1tt, P. Hewton, In Eraluation of the Student Ald Program in Kontuok, addross Givon in oonnection with the Thirtoogth annual Kentucky Bdueational Conferenoe, University of Kentuoky, Ootober 31, 1936.

Rooserelt, Frankin D., statement on signing Breontive Ordor No. 7086, June 26, 1935.

Statement Regarding Willard $\mathrm{B}$. Givens Iotter of liay 27 , (1943), Ilational Youth Ldministration, June, 1943. 